\title{
Anti-ELAB Movement, National Security Law, and heterogeneous institutional trust in Hong Kong
}

\author{
Hans H. Tung ${ }^{1,2 *}$ (D), Ming-Jen $\operatorname{Lin}^{2,3}$ (D) and Yi-Fan $\operatorname{Lin}^{3}$ \\ ${ }^{1}$ Department of Political Science, National Taiwan University, Taipei, Taiwan, ${ }^{2}$ Center for Research in Econometric Theory \\ and Applications, National Taiwan University, Taipei, Taiwan and ${ }^{3}$ Department of Economics, National Taiwan University, \\ Taipei, Taiwan \\ ${ }^{*}$ Corresponding author. E-mail: hanstung@ntu.edu.tw
}

(Received 19 May 2021; revised 5 September 2021; accepted 13 September 2021)

\begin{abstract}
How does repression on opposition protests affect citizens' institutional trust under dictatorships? There has been a burgeoning literature investigating empirically both long- and short-term impacts of protests and their repression on citizens' political preferences in both democratic and nondemocratic contexts. Yet, the literature tells us relatively little about how the above question could be answered. This paper tries to answer this question by taking advantage of a recent natural experiment in Hong Kong when Beijing suddenly adopted the National Security Law (NSL) in June 2020 to repress dissidents' protest mobilization. Our findings are twofold. First of all, the NSL drove a wedge in the Hong Kong society by making the proestablishment camp more satisfied with the post-NSL institutions on the one hand, while alienating the pro-democracy camp who lost tremendous trust in them on the other. Second, our study also reveals that one's trust in institutions is significantly associated with the regimes' ability to curb protesters' contentious mobilization. The Hong Kongers who had higher confidence in the NSL to rein in protests would also have a greater level of trust than those who didn't. The effect, however, is substantially smaller among pro-democracy Hong Kongers except for their trust in monitoring institutions. As Beijing is transforming Hong Kong's current institutions from within hopes of bringing about a new political equilibrium, our study helps provide a timely assessment of Hong Kong's institutional landscape and sheds light on how likely this strategy can work.
\end{abstract}

Key words: Institutional trust; Anti-ELAB Movement; contentious politics; repression; authoritairan institutions; National Security Law

\section{Introduction: institutional trust in a post-repression period}

How does repression on opposition protests affect citizens' institutional trust under dictatorships? There has been a burgeoning scholarly interest recently in investigating empirically both long- and short-term impacts of protests and mass mobilizations on citizens' political preferences in both democratic and nondemocratic contexts (Madestam et al., 2013; Sangnier and Zylberberg, 2017; Mazumder, 2018; Frye and Borisova, 2019; El-Mallakh, 2020; Tertytchnaya and Lankina, 2020). Moreover, this growing literature also well extends to how their repressions in different forms affect the same set of outcomes (Lawrence, 2016; Rozenas and Zhukov, 2019; Dinas and Northmore-Ball, 2020; Neundorf and Pop-Eleches, 2020; Curtice and Behlendorf, 2021; Desposato et al., 2021; Wang, 2021). Yet, the literature tells us relatively little about how the above question could be answered.

Why does it matter to expand the literature to include the relationship between protest crackdown and the public's institutional trust? For one thing, the comparative authoritarianism literature has told (C) The Author(s), 2021. Published by Cambridge University Press. This is an Open Access article, distributed under the terms of the Creative Commons Attribution-NonCommercial-NoDerivatives licence (http://creativecommons.org/licenses/by-nc-nd/4.0), which permits non-commercial re-use, distribution, and reproduction in any medium, provided that no alterations are made and the original article is properly cited. The written permission of Cambridge University Press must be obtained prior to any commercial use and/or adaptation of the article. 
us, beyond their nominal functionalities, the political significance of authoritarian institutions in bringing about better regime stability and performance through power-sharing and cooptation (Gandhi, 2008; Kim and Gandhi, 2010; Boix and Svolik, 2013). As a result, in terms of understanding the effects of repression on the survival and prosperity of a dictatorship, it's not just about knowing how it might give rise to backlash movements (Curtice and Behlendorf, 2021) or foster anti-regime sentiment in the long run (Wang, 2021), but also about figuring out its effect on citizens' trust in institutions.

For another, when dictators use subtler forms of repression such as further restricting citizens' (already not so many) civil liberties to preserve regime stability without losing too much legitimacy (Escribá-Folch, 2013), the implementation of such a softer approach must be more embedded in the existing institutional framework than one with more violence involved. The effectiveness and legitimacy of such a strategy, however, critically hinges on the credibility of the existing authoritarian institutions among the public. One good example is Thailand's 2017 constitution in which a new electoral system was introduced to give the military a dominant power in appointing members in the Senate, an unelected body, that would work together with the popularly elected House of Representatives to pick a prime minister. ${ }^{1}$ The fact that such political maneuvering was approved previously in August 2016 by a referendum and then legitimized with King's signature clearly shows that a soft repression like this certainly stood a better chance to succeed when Thailand's referendum and monarchy as political institutions enjoyed enough trust.

Now since Beijing has adopted a very similar institutionalist approach to handling Hong Kong's situation, understanding the effects of the recently passed National Security Law (hereafter NSL) on Hong Kongers' institutional trust therefore becomes very relevant. We examine the NSL's short-term effect by studying Hong Kong's recent contentious episode of the anti-Extradition-Law-Amendment-Bill (ELAB) Movement between 2019 and 2020. The law not only stipulates various actions taken by protesters during the Anti-ELAB Movement as national security infringements, but also authorizes the creation of the centrally directed Office for Safeguarding National Security commanding a wide range of powers in law enforcement and adjudication. As its passage in China's People's Congress last June (2020) came as a shock to most people in Hong Kong, the two surveys we conducted right before and after it allow us to identity its effect on Hong Kongers' trust in various related political institutions.

We find that, for all the institutions under scrutiny in this study, ${ }^{2}$ the NSL as a soft repression ${ }^{3}$ did have an effect on one's institutional trust across the board. However, the effect is found to be heterogeneous between pro-democracy and pro-establishment respondents with the former having negative while the latter having positive NSL-induced effect on institutional trust. Based on the insights from the comparative authoritarianism literature, we argue that the difference arises from one's sense of regime inclusiveness. While it's hard for our survey to interview real regime insiders, the pro-establishment respondents who identified themselves with the regime certainly would have higher institutional trust when repression could suppress the social unrest in Hong Kong and help strengthen the established institutions in their favor. For pro-democracy counterparts, however, their institutional trust plunged as predicted since repression not only consolidated the institutions that might impair Hong Kong's democratic prospect, but also sabotaged those that had helped sustain its rule of law, widely regarded as integral to Hong Kongers' identity.

Moreover, our results also suggest that the effect of repression on institutional trust is conditioned by how well one perceives the strategy to be working in reining in protesters' mobilization. We find the optimists of the NSL to be associated with a higher level of institutional trust than the pessimists. We

\footnotetext{
${ }^{1}$ Jonathan Head. 'Thailand's constitution: New era, new uncertainties.' BBC, 7 April 2017. https://www.bbc.com/news/ world-asia-39499485 (accessed: 20 April 2021).

${ }^{2}$ This study included the following institutions: The Central Government, the Chief Executive, the Court, the Legislative Council (LEGCO), the Liasion Office, the People's Liberation Army, the Police, and the Registration and Electoral Office (REO).

${ }^{3}$ We view the NSL as soft only in relative terms vis-á-vis a Tiananmen-style crackdown or a complete takeover. While there is certainly no denying of Beijing's heavy-handed efforts to use NSL as a legal means to put almost all major political dissidents behind bars, there is still a qualitative difference between the NSL as a repressive instrument and violent quasi-military actions.
} 
argue that, from an informational perspective, compared to the pessimists, the unexpected NSL as a shock updated both the pro-establishment optimists with the newly gained strength for the institutions and the pro-democracy ones with a lower likelihood for future political interventions to further disrupt the institutional quality since the repression had worked. ${ }^{4}$

Finally, we also find that, compared to the executive branch of the institutions included in this study, the NSL didn't hurt the pro-democracy respondents' institutional trust in Hong Kong's Court very much - less than $10 \%$ lower than the pre-NSL level. While this finding might simply attest to Hong Kongers' convention in having higher trust for the judicial branch (Chan and Chan, 2006), it however has a profound implication for Hong Kong's post-NSL political development as Beijing dramatically tightens its grip on this former British colony. ${ }^{5}$ As Lhrmann and Lindberg (2019) point out, the ongoing third wave of autocratization often takes place under a legal façade whereby restricting citizens' political rights is legitimized via the procedures of existing institutions such as legislatures ${ }^{6}$ or courts. The findings of our study suggest that Hong Kong might very well be such a case where its relatively trusted Court could be instrumental to legalizing and legitimizing the weakening of the political opposition and further erosion of citizens' political rights and freedoms. ${ }^{7}$

The paper is structured as follows. Section 2 presents our theoretical perspectives to be empirically tested and the hypotheses derived from them. We also provide in Section 3 a discussion of Hong Kong's political context relevant to our study. It is then followed by Section 4 where the data collection and empirical strategies are explicated. Section 5 presents our empirical findings and robustness checks. Finally, Section 6 concludes.

\section{Theoretical discussion and hypotheses}

Since David Easton (1975), political scientists have mainly studied institutional trust through the lens of two concepts he helped develop: diffuse and specific support. The latter defines trust as one's level of satisfaction of a specific institution according to its performance and therefore tends to be shortterm in nature given possible fluctuations in government policies. In contrast, the former defines trust as one's more general faith in a larger political system and therefore is basically one's long-term belief largely shaped by the political socialization he or she went through previously. In this paper, we propose several new theoretical perspectives to enrich this framework and better explain the effects of protest repression on institutional trust in times of turmoil.

\subsection{NSL's heterogeneous effects}

First and foremost, as we have mentioned above, the recent institutionalist turn in the comparative authoritarianism literature has put the inclusiveness of political institutions under dictatorships at center stage. Beyond their nominal functionalities, the key reason for authoritarian institutions to be the mainstay of regime stability is their ability to credibly include and coopt all the major actors whose support is essential to dictators' rule. As the theory goes, the people who are institutionally included

\footnotetext{
${ }^{4}$ What should be noted here is that this part of our findings is only correlational. While the NSL as a repressive means did come as an external shock, which made its effect on institutional trust causal, one's assessment of the NSL's effect on protests was however self-reported and not manipulated in the survey. As a result, apart from the informational perspective we provided above, the causal direction can also go the other way around. That is, we cannot exclude the possibility that those who had lower (higher) institutional trust would also under (over)-estimate the NSL's ability to suppress the protests.

${ }^{5} J o h n$ Sudworth. 'China's parliament remakes Hong Kong in its own image.' BBC 11 March 2021. Available at: https:// www.bbc.com/news/world-asia-china-56364912 (accessed: 30 March 2021).

${ }^{6}$ For example, not only did Hitler come to power legally, but the Enabling Act in 1933 he used to nail the coffin of the Weimar democracy was also procedurally legitimate (Lhrmann and Lindberg, 2019: 1105).

${ }^{7}$ Natalie Wong and Jeffie Lam. 'Hong Kong's national security law eight months on: arrests, moves to ensure "patriots" take charge, university cuts off student union.' South China Morning Post 28 February 2021. Available at: https://www. scmp.com/news/hong-kong/politics/article/3123427/hong-kongs-national-security-law-eight-months-arrests-moves (accessed: 30 March 2021).
} 
and shared with resources will be incentivized to support not only the institutions that make the cooptation possible, but also the regime itself (Boix and Svolik, 2013). While the theoretical framework is initially formulated for analyzing the intra-elite relationship, the idea of inclusiveness can be readily extended to the public opinions of rank-and-file citizens. Neundorf et al. (2020) adopt this approach by tapping into the cross-national variation in the pre-transition authoritarian inclusiveness - defined as 'wider redistribution of socioeconomic and political benefits' - for explaining citizens' democratic support in post-authoritarian countries. They find that the support tends to be lower among the citizens in countries with a more inclusive regime before the transition since their living standards might not necessarily be substantially enhanced under democracy.

Along the similar line, since our focus is within and not across countries, we argue that institutional trust can also vary between ordinary citizens who feel themselves a part of the regime and those who don't. As far as the effect of repression is concerned, this argument implies that repression will have heterogeneous effects between these two groups. For those who perceive themselves to be outcasts, repressions can further alienate them from the regime and even have a long-term dampening effect on their trust in political institutions and the government (Lawrence, 2016; Dinas and Northmore-Ball, 2020; Desposato et al., 2021; Wang, 2021). For those self-perceived regime insiders, however, the ability of the regime to clamp down on protest mobilizations and restore social order should have an opposite effect of boosting their confidence in the regime and its institutions. We, therefore, hypothesize that:

Inclusiveness hypothesis: The NSL exerted a negative effect on pro-democracy Hong Kongers' institutional trust, but induced a positive one on pro-establishment counterparts' institutional trust.

\subsection{Protest expectations}

Second, while protest repression certainly presents a shock to everyone, it doesn't mean its effect will necessarily be uniform to all. This, therefore, creates another layer of heterogeneity in repression's effect on institutional trust. From an informational perspective, protest repression as an external shock brings people new information about their governments, which can also help them - assuming they are Bayesian - update their levels of institutional trust by forming expectations about the future of political institutions. Frye and Borisova (2019), for example, provide a similar reasoning that unexpected protests in Russia gave its citizens who had a strong prior about the government's repression intention new information regarding the ruling elite's tolerance of public opposition, which updated their trust in political institutions upward. In the context of repression, we argue that this Bayesian theory gives rise to different predictions according to one's assessment of its effects. Among the regime insiders, those who believe repression to be effective at taming protesters will find institutions more trustworthy as this piece of new information reconfirms them the resolve and ability of the regime to protect the institutions that benefit them. By contrast, those who don't hold the same belief will lower their trust for expecting declining benefits from their institutional memberships.

Among the regime outsiders, despite for a different reason, the direction of the prediction remains unchanged. While repression is predicted to induce a negative effect on their institutional trust since they derive no utility from political institutions, the degree of the downward Bayesian update will be higher among those who perceive the effect of a repression shock to be low. The reason is that, if the dictator is unable to rein in protest mobilizations through repression, it also implies that there might be more protests and greater needs for repressions that make institutions even less inclusive and trustworthy in the future. By contrast, if repression works from the outset, then it is less likely for such actions to be taken, thus making political institutions 'less' untrustworthy. Combined, the Bayesian perspective on repression as a shock gives us a hypothesis:

Informational hypothesis: For both regime insiders and outsiders in Hong Kong, the lower one's protest expectation was-or, equivalently, the more effective one expected the crackdown to be -, the higher his or her institutional trust would be. 
This second hypothesis also echoes the recent findings by Rozenas and Zhukov (2019) that people's loyalty under repressive dictatorship is contingent on the credibility of the dictator's retribution threat to the opposition.

\section{Background on the Hong Kong case: the birth and death of a movement society}

Given the centrality of social movements and political activism in Hong Kong's political landscape (Cheng, 2016), its recent Anti-ELAB Movement - began in June 2019 and officially ended with the passage of the NSL in June 2020 - provides us a great context for testing our theoretical arguments and the effects of the NSL. First of all, since the sovereignty handover from the UK to the People's Republic of China in 1997, Hong Kong has become China's Special Administrative Region (SAR) and was promised to enjoy self-governance under an ad-hoc political framework of 'One Country, Two Systems' (OCTS) for 50 years. As a result, under its Basic Law, the framework had, thus, created a hybrid regime in Hong Kong where, on the one hand, new authoritarian institutions such as the legislature (i.e., the LegCo) and the indirect election for the Chief Executive (the head of the government) were adopted, ${ }^{8}$ and, except for the universal suffrage, several liberal democratic components such as civil liberties, the rule of law, and the judicial independence, on which Hong Kong's market economy was critically predicated, also co-existed on the other (Ma, 2007).

Before the NSL, the two components above jointly determined the level of inclusiveness of the regime for both elites and rank-and-file citizens in Hong Kong. On the one hand, partially inheriting from the colonial period, the regime coopted powerful elites through various authoritarian institutions such as the LegCo and indirect elections for key government positions (Fong, 2013). ${ }^{9}$ For example, the Chief Executive was elected indirectly by a small 'selectorate' - a 1200-people Electoral Committee composed of politicians (representatives at all levels of local legislatures) and a limited number of elites from a variety of professions (29 in total; e.g., legal profession, business community, medical profession, etc.). Furthermore, in the LegCo, half of the seats were filled by representatives elected from each of the 'functional constituencies' - the same groups of professions for the Chief Executive's Electoral Committee - , while the other half were popularly elected from five different districts. These institutions were designed to make the interests of the coopted social elites aligned with those of the regime.

On the other hand, for ordinary citizens, the sense of regime inclusiveness à la Neundorf et al. (2020), however, could only be derived from the civil liberties granted to them under the OCTS framework, and, as Hong Kong's political development since 1997 has shown, this sense was gained to a large extent by means of the most contentious form of the civil liberties: protests. At the inceptive stage of the Anti-ELAB Movement when the contentious situation was escalating after the 12 June confrontation in 2019, ${ }^{10}$ an authoritative and internationally known bond credit rating company, Moody's Investors Service, published an article, 'Moody's affirms Hong Kong's Aa2 ratings, maintains stable outlook' on 5 July $2019,{ }^{11}$ where the company wrote:

The rating includes Moody's assessment of political risk for Hong Kong that takes into account periodic challenges to the government's policies in recent years, and particularly in large-scale

\footnotetext{
${ }^{8}$ We by no means try to suggest here that the colonial period in Hong Kong was necessarily more democratic and liberal than it is today. The conclusions of our study do not depend on the comparison in either way. What we would like to emphasize here, however, is that, compared to the British colonizers, Beijing did try to set up a different kind of hybrid regime by introducing new authoritarian institutions.

${ }^{9}$ Despite the continuity, Fong (2013), however, also finds a change in the post-handover state-business relationship where business people were substantially sidelined.

${ }^{10}$ Damien Gayle, Kate Lyons, Verna Yu. Hong 'Kong protest: police fire teargas at demonstrators - as it happened.' 13 June 2019. Available at: https://www.theguardian.com/world/live/2019/jun/12/hong-kong-protest-demonstrators-and-police-faceoff-over-extradition-bill-live (accessed: 22 April 2021).

${ }^{11}$ The article is available at https://www.moodys.com/research/Moodys-affirms-Hong-Kongs-Aa2-ratings-maintains-stableoutlook--PR_403359?fbclid=IwAR3rPvPQQDZ3PrpiY_HvEdEVhnZabB2B9W_Ix-iXRJBm5dGcx8L4qWsP2QA (accessed: 22 April 2021).
} 
protests by the population. Such protests are part of the checks and balances in place in Hong Kong, that support institutional strength. Signs that checks and balances weaken would be a negative for Hong Kong's credit profile. [italics added]

Moody's statement bears strong testimony to the centrality of protests as the essential means on which ordinary Hong Kongers depended for enjoying the liberal democratic part of the hybrid regime where institutional checks and balances were absent. Table 1 documents all the major contentious episodes since 1997, including the contested polices that triggered the protests, the information and turnout of the protests, and the government's responses to them.

It is clear from the table that, before the final blow of the NSL was imposed in 2020, except for the protest over the 'NPCSC's Power of Final Interpretation' in 1999 that might fail to override the government policy for the lack of enough critical mass for the movement, Hong Kongers were always able to push back against Beijing's and the SAR government's efforts to bring Hong Kong closer to the mainland economically, politically, and socially. This protest-based checks-and-balances model, however, was not sustainable for the long-run given the tutelary nature of this hybrid regime. In other words, while the SAR government yielded to protesters' mass mobilization, it didn't really stop the Central Government in Beijing from forging ahead with its political agenda in Hong Kong to tilt the balance toward 'One Country' over 'Two Systems' within the OCTS framework, especially since Xi Jingping became China's supreme leader in 2012.

The watershed moment was the year of 2014 when Beijing put off again its promise to grant the full version of the universal suffrage to Hong Kongers regarding the elections for both the Chief Executive and the LegCo. Beijing's 2014 decision first gave rise to the 'Umbrella Revolution' where students and political activists occupied the square in front of the Admiralty MRT station and the government compounds. Later on, the political grievances against Beijing in Hong Kong grew dramatically and there were various demonstrations organized to protest Beijing's political agenda such as the patriotism education and the NSL. In early 2019, the controversy rose again when the SAR government tried to introduce a milder version of the Law, according to which suspects who were accused of committing a crime could be expedited to China for trials. Given the huge discrepancy in judicial systems between China (Continental Civil Law) and Hong Kong (Common Law), the bill encountered a strong reaction from Hong Kong's democrats and civil society, which eventually evolved into the Anti-ELAB Movement that persisted until coronavirus disease 2019 (COVID-19) arrived in early 2020 and was bought to an end abruptly by the NSL.

\section{Empirical strategies}

\subsection{Data collection, sample, and variable construction}

To test the hypotheses specified in Section 2, this study exploits the NSL as an external shock by conducting two surveys with almost the same set of questions in Hong Kong immediately before and after its passage. On 21 May 2020, the Chinese government announced that a new version of the NSL tailor-made for Hong Kong would be deliberated and voted on in the coming session of the National People's Congress held in Beijing between 22 and 28 May 2020. The news brought a shock not only to Hong Kong, but also to the rest of the world since the intensity of the Anti-ELAB Movement had gradually tapered off owing to the COVID-19 outbreak since January 2020. The draft was eventually passed on 28 May.

The first survey began on 15 May and ended on 21 May, the day of the Chinese government's initial announcement about the NSL. We recruited 1, 424 Hong Kong respondents from the online panel maintained by the Rakuten Insight, a global survey company and the surveys were scripted in Qualtrics. The sampling strategy was quota sampling, taking into consideration Hong Kong's population distributions of age and gender. ${ }^{12}$

\footnotetext{
${ }^{12}$ See Table B.1 in Appendix B for both the sample and the population distributions in age, education, gender, and residential district. While both distributions are substantially close, as most online surveys, our sample is still a bit younger and
} 
Table 1. Hong Kong's contentious politics: major episodes since 1997

\begin{tabular}{|c|c|c|c|}
\hline Year & Contested policy & Protests (turnout) & Government response \\
\hline 1999 & $\begin{array}{l}\text { The NPCSC's (National People's Congress } \\
\text { Standing Committee) Power of Final } \\
\text { Interpretation Established (Hong Kong } \\
\text { Permanent Residency in the Basic Law) }\end{array}$ & $\begin{array}{l}\text { Lawyers' Silent March, } 30 \text { June } 1999 \\
\quad \text { (More than } 600 \text { legal professionals) }\end{array}$ & $\begin{array}{l}\text { The Decision of Hong } \\
\text { Kong's Court of Final } \\
\text { Appeal Overruled }\end{array}$ \\
\hline 2003 & The National Security Bill (Article 23) & $\begin{array}{l}\text { First 'July } 1 \text { st March' since the handover, } \\
1 \text { July } 2003 \text { ( } 0.5 \text { million citizens) }\end{array}$ & The Bill Withdrawn \\
\hline 2012 & $\begin{array}{l}\text { The Moral and National Education } \\
\text { Curriculum Policy }\end{array}$ & $\begin{array}{l}\text { The Anti-National Education Movement, } \\
29 \text { July } 2012 \text { (19-32 thousand citizens } \\
\text { according to the police estimation) }\end{array}$ & The Policy Withdrawn \\
\hline 2014 & $\begin{array}{l}\text { The } 2014 \text { NPCSC Decision on Hong Kong } \\
\text { (831 Decision) }\end{array}$ & $\begin{array}{l}\text { Occupy the Central and The Umbrella } \\
\text { Movement, } 26 \text { September }-15 \\
\text { December } 2014 \text { (1.2 millions) }\end{array}$ & $\begin{array}{l}\text { The Electoral Reform } \\
\text { Proposal Rejected at } \\
\text { LEGCO in June } 2015\end{array}$ \\
\hline $2019-20$ & $\begin{array}{l}\text { The Extradition Law Amendment Bill } \\
\text { (ELAB) }\end{array}$ & $\begin{array}{l}\text { Anti-ELAB Movement, } 12 \text { June 2019- } \\
\text { January } 2020 \text { (millions) }\end{array}$ & The NSL imposed \\
\hline
\end{tabular}

To make sure zero suspicions about the NSL's adoption and wide awareness of it among Hong Kongers, we waited until 10 June, nearly 2 weeks after the law had been officially passed at the National People's Congress in Beijing, to administer the second round, which ended on 26 June. As for the sample attrition of the post-NSL round, given the short span between the two surveys, we were able to retain almost $90 \%$ of our pre-NSL respondents for our post-NSL round $(1,256) .^{13}$

We included in both surveys questions regarding respondents' basic demographics (e.g., gender, age, and education), attitudes and beliefs regarding Hong Kong's economic and political prospects, protest expectations (to be detailed in Section 5.2 and Appendix C), institutional trust (our main variables of interest), and political stances. See Table B.1 in Appendix B for how our variables were constructed from these questions. While our empirical design certainly enjoyed the advantage of having the NSL as a natural experiment, what should be noted here is that soliciting people's (including both protesters and non-protesters) political attitudes in a contentious context where the freedom of expression was potentially under threat could be difficult. To address the issue, we not only avoided asking our respondents overly sensitive questions such as their previous protest participation, but also employed several de-identification measures to protect them (see Appendix A for details).

\subsection{Estimation}

The paper's main objectives are to estimate (1) the heterogeneous effect of NSL on institutional trust according to one's sense of regime inclusiveness and (2) the correlation between one's post-NSL protest expectation and his or her institutional trust. To estimate such effects, we first tapped into the exogenous variation in the institutional trust induced by the NSL. For each institution $j$, individual $i$ 's institutional trust $Y$ at time $t$ can be empirically modeled as:

$$
Y_{i j t}=\beta N S L_{t}+\lambda C_{i t}+\alpha_{i t}+\gamma_{i j}+\delta_{j t}+\varepsilon_{i j t}
$$

NSL is an indicator variable with 1 denoting the post-NSL period and its coefficient $\beta$ captures the average effect of the NSL as a shock to $i$ 's trust in institution $j$. $C$ is the variable that denotes $i$ 's post-NSL shock in his or belief of Hong Kong society's collective action potential, and its coefficient,

more educated than the actual population in Hong Kong. The issue is addressed in Appendix E.4 by re-estimating our models using the sample re-weighted according to the population distributions above.

${ }^{13}$ Our two-round sample not only has a low attrition rate, but, as Table B.1 documents, the post-NSL sample distribution is also very close to the pre-NSL one. To make sure our results were robust to different attrition scenarios, we further implemented the Lee bounds estimator (Lee, 2009) in Section 5.4. We greatly appreciate an anonymous reviewer for the suggestion. 
$\lambda$, is the parameter of interest that captures $C$ 's effects on $i$ 's institutional trust. If significant, our theory predicts $\lambda$ 's sign to be positive. The model also includes several control variables. First, $\alpha_{i t}$ is a set of individual-time fixed effects that captures other time-varying individual-level attitudes and beliefs that might also affect one's institutional trust. In contrast, $\delta_{j t}$ is a set of institution-time fixed effects that accounts for the influence arising from institutions themselves. For example, an institutional change such as the ongoing electoral reform in Hong Kong that drastically changes how the Chief Executive and LegCo members are elected will definitely have an impact on people's trust in them. In addition, $\gamma_{i j}$ is a collection of time-invariant variables at both individual and institutional levels that might also affect institutional trust. For instance, depending on one's view toward the colonial period, he or she might place a higher or lower trust from the very beginning in the institutions that are part of the colonial legacies compared to those created after the handover in 1997. In other words, the institutional origin might play a role in determining one's institutional preferences. Alternatively, the demographic variables that don't change over time cannot be ignored either. The last variable $\varepsilon_{i j t}$ is the error term.

The estimation of $\beta$ is straightforward. We took advantage of the NSL as an exogenous shock to the vast majority of Hong Kongers between the two surveys by pooling their responses together to obtain individual-wise repeated observations over the two periods, i.e., a panel data structure. Since $C$ was only measured in the post-NSL period, the panel specification is given by:

$$
Y_{i j t}=\beta N S L_{t}+\alpha_{i t}+\gamma_{i j}+\delta_{j t}+\varepsilon_{i j t}
$$

Moreover, to estimate $\lambda$ in (1), we first notice that the individual-institution fixed effects, $\gamma_{i j}$, can be readily eliminated by first-differencing (1) to obtain:

$$
\Delta Y_{i j 1}=\lambda C_{i 1}+\alpha_{i}^{\prime}+\delta_{j}^{\prime}+\varepsilon_{i j}^{\prime}
$$

where $\Delta Y_{i j 1}=Y_{i j 1}-Y_{i j 0}$ indicates the difference between $i$ 's pre-NSL and post-NSL trust in institution $j$, and, given the absence of any collective action shock before the law $\left(C_{i 0}=0\right), \Delta C_{i 1}=C_{i 1}$. Furthermore, $\alpha_{i}^{\prime}=\alpha_{i 1}-\alpha_{i 0}$ accounts for other NSL-induced effects on one's institutional trust, and $\delta_{j}^{\prime}=\delta_{j 1}-\delta_{j 0}$ captures post-NSL institutional shocks. Finally, the error term is also re-specified as $\varepsilon_{i j}^{\prime}=\varepsilon_{i j 1}-\varepsilon_{i j 0}$. What should be noted here is that, given the extremely short span between the two surveys (about 2 weeks), institutional shocks were essentially non-existent for this study and therefore $\delta_{j}^{\prime}$ should be set to zero to yield:

$$
\Delta Y_{i j 1}=\lambda C_{i 1}+\alpha_{i}^{\prime}+\varepsilon_{i j}^{\prime}
$$

Finally, as our theories predict, the effects of the NSL should be heterogeneous between respondents with different perceptions of regime inclusiveness. To incorporate the effect heterogeneities, the estimation equation is further generalized to be as follows:

$$
\Delta Y_{i j 1}=\left\{\begin{array}{lc}
\lambda_{P D} C_{i 1}+\alpha_{i}^{\prime}+\varepsilon_{i j}^{\prime} & \text { Pro-Democracy } \\
\lambda_{P E} C_{i 1}+\alpha_{i}^{\prime}+\varepsilon_{i j}^{\prime} & \text { Pro-Establishment }
\end{array}\right.
$$

\section{Empirical findings and robustness checks}

\subsection{National Security Law and institutional trust}

To measure institutional trust, we asked respondents in both pre- and post-NSL surveys to rate their levels of trust in eight government institutions using a 100-point scale where 0 denotes 'no trust at all' and 100 denotes 'full trust.' Both central-level - the Central Government, the Liaison Office, the People's Liberation Army (PLA) - and local institutions - the Chief Executive, the Court, the 
LegCo, the Police, and the Registration and Electoral Office - were included. We took an average of one's levels of trust in the three Central Government institutions that were directly responsible for the NSL legislation and crackdown to construct our main dependent variable of interest, Average Central Government Trust (ACGT).

To formally estimate the NSL's effects on the average government trust, we took advantage of our repeated observations of the same set of respondents right before and after the Law was passed by pooling together the data from the two surveys for our regressional analyses. Moreover, to test our theoretical argument about the NSL's heterogeneous effects, we further divided our respondents further into three groups of political stances: (1) pro-democracy (PRO_DEMO, self-perceived regime outcast), (2) pro-establishment (PRO_ESTAB, self-perceived regime insider), and (3) no stance (NO_STANCE) (see Table B.1 in Appendix B for details). ${ }^{14}$ Given our tripartite typology of political stances, we set the no-stance to be the baseline for the analyses. ${ }^{15}$

Our findings not only confirm the NSL's effects on one's institutional trust (Inclusiveness hypothesis), but also paint a very polarized Hong Kong. As Table 2 (model (1) baseline) documents, the NSL induced a mild upward shift by roughly $6 \%$ for no-stancers in their average institutional trust in the Central Government institutions. Furthermore, Figure 1 visualizes more clearly the NSL's heterogeneous effects vis-á-vis is the baseline between pro-democracy and pro-establishment Hong Kongers. On the one hand, the NSL substantially reduced the former's trust by large margins $(-26 \%)$, while induced diametrically opposed effects $(17 \%)$ on institutional trust for those who leaned toward the establishment on the other.

Moreover, the estimates are also very stable and robust with the addition of different sets of con$\operatorname{trols}^{16}$ : (1) model (2): one's probability assessment of how likely the elected opposition LegCo members were going to be disqualified after the September election in $2020^{17}$ (DQ_OPM), (2) model (3): one's expectations of Hog Kong's future economy (HKECON) and social welfare (WELEXP), (3) model (4): demographic variables (age, gender, education, residential district, class, and occupation), and (4) model (5): the full specification that includes all the variables above along with one's stance in the first survey (PRO_DEMO_PRE and PRO_ESTAB_PRE). ${ }^{18}$

What is worth noting here is that the full specification also gives us several additional insights into Hong Kongers' institutional trust independent of the NSL's effect. According to Table 2, one's age is found consistently to be a significant positive predictor of his or her trust level in the Central Government institutions on average (models (2) and (5)). We also find additional correlational

\footnotetext{
${ }^{14}$ In both surveys, respondents were asked to choose a political stance according to a five-way classification: Centrist, Democrat, Establishmentarian, Localist, and No-Stance. To avoid a large measurement error, we further bundled the Localist with the Democrat respondents ('Pro-Democracy') and the Centrist with the Establishmentarian ones ('Pro-Establishment') respectively to make it a three-way classification for our following regressional analyses. Moreover, what has to be noted here is that some people actually switched from their pre-NSL political stances to others in the post-NSL survey, which were used in the our statistical analyses. The changes could be induced by the NSL and implied that one's choices of political stance and institutional trust could be correlated with each other. We address this issue in the section on robustness checks to make sure our estimates are robust to such correlations.

${ }^{15}$ Descriptively, the stance-wise comparisons in Table B.2 (Appendix B) establish that there are very substantial differences in average institutional trusts at the central level among the three political stances at both aggregate and disaggregate levels. The average levels of trust the pro-establishment respondents placed in Central Government institutions during both surveys were around 50 vis-á-vis is 9 given by the pro-democracy counterparts. As far as no-stancers are concerned, their institutional trusts lay right in-between the other two stances across the board. Moreover, consistent with our prediction of the NSL's heterogeneous effects across political stances, the stripplots in appended Figures B.1 and B.2 (red dots representing the means) indicate that, on average, the NSL caused pro-democracy respondents to lower their institutional trusts across the board, but exerted opposite effects on pro-establishment and no-stance ones, with the former showing a greater magnitude.

${ }^{16}$ See Appendix D.1 for the results of individual Central Government institutions. The empirical patterns remain unchanged and equally robust.

${ }^{17}$ After our surveys were administered, the election was then postponed first to September 2021 due to the pandemic, and then to December 2021 again to gain more time for the electoral reforms Beijing initiated.

${ }^{18}$ Since one's pre-NSL stance was certainly independent of the NSL, controlling for it in the regressions makes the results robust to how much one's stance was swayed by the NSL.
} 
Table 2. NSL's effects on institutional trust: ACGT

\begin{tabular}{|c|c|c|c|c|c|}
\hline Variables & BASELINE (1) & DEMOGR (2) & $\mathrm{DQ}(3)$ & ECON (4) & FULL (5) \\
\hline NSL & $\begin{array}{l}5.637^{\star \star} \\
(2.349)\end{array}$ & $\begin{array}{l}5.073^{\star \star} \\
(2.331)\end{array}$ & $\begin{array}{l}6.209^{\star \star \star} \\
(2.339)\end{array}$ & $\begin{array}{l}13.79^{\star \star \star} \\
(3.164)\end{array}$ & $\begin{array}{l}13.25^{\star \star \star} \\
(3.211)\end{array}$ \\
\hline PRO_DEMO & $\begin{array}{c}-1.385 \\
(2.291)\end{array}$ & $\begin{array}{c}-1.095 \\
(2.207)\end{array}$ & $\begin{array}{c}-1.285 \\
(2.274)\end{array}$ & $\begin{array}{c}-0.851 \\
(2.375)\end{array}$ & $\begin{array}{c}-0.704 \\
(2.096)\end{array}$ \\
\hline PRO_ESTAB & $\begin{array}{c}0.0723 \\
(2.490)\end{array}$ & $\begin{array}{c}0.418 \\
(2.402)\end{array}$ & $\begin{array}{c}1.309 \\
(2.485)\end{array}$ & $\begin{array}{c}-1.493 \\
(2.555)\end{array}$ & $\begin{array}{c}-0.367 \\
(2.302)\end{array}$ \\
\hline NSL × PRO_DEMO & $\begin{array}{c}-26.20^{\star \star \star} \\
(2.918)\end{array}$ & $\begin{array}{c}-25.51^{\star \star \star} \\
(2.898)\end{array}$ & $\begin{array}{c}-23.46^{\star \star \star} \\
(2.951)\end{array}$ & $\begin{array}{c}-27.83^{\star \star \star} \\
(3.015)\end{array}$ & $\begin{array}{c}-23.88^{\star \star \star} \\
(2.948)\end{array}$ \\
\hline NSL $\times$ PRO_ESTAB & $\begin{array}{l}17.47^{\star \star \star} \\
(3.409)\end{array}$ & $\begin{array}{l}18.22^{\star \star \star} \\
(3.406)\end{array}$ & $\begin{array}{l}15.17^{\star \star \star} \\
(3.403)\end{array}$ & $\begin{array}{l}17.77^{\star \star \star} \\
(3.479)\end{array}$ & $\begin{array}{l}16.62^{\star \star \star} \\
(3.399)\end{array}$ \\
\hline PRO_DEMO_PRE & & & & & $\begin{array}{c}-9.402^{\star \star \star} \\
(1.446)\end{array}$ \\
\hline PRO_ESTAB_PRE & & & & & $\begin{array}{l}8.199^{\star \star \star *} \\
(1.711)\end{array}$ \\
\hline HKECON & & & & $\begin{array}{c}-2.913^{\star \star} \\
(1.151)\end{array}$ & $\begin{array}{c}-3.275^{\star \star \star} \\
(1.193)\end{array}$ \\
\hline WEL_EXP & & & & $\begin{array}{c}-6.952^{\star \star \star} \\
(0.859)\end{array}$ & $\begin{array}{c}-5.709^{\star \star \star} \\
(0.872)\end{array}$ \\
\hline DQ_OPM & & & $\begin{array}{c}-0.237^{\star \star \star} \\
(0.0290)\end{array}$ & & $\begin{array}{c}-0.180^{\star \star \star} \\
(0.0297)\end{array}$ \\
\hline Age & & $\begin{array}{l}0.363^{\star \star \star} \\
(0.0610)\end{array}$ & & & $\begin{array}{c}0.197^{\star \star \star} \\
(0.0630)\end{array}$ \\
\hline Female & & $\begin{array}{c}-1.044 \\
(1.294)\end{array}$ & & & $\begin{array}{c}-1.659 \\
(1.292)\end{array}$ \\
\hline \multicolumn{6}{|l|}{ Education (baseline: primary) } \\
\hline Lower secondary & & $\begin{array}{c}7.154 \\
(8.765)\end{array}$ & & & $\begin{array}{c}3.023 \\
(7.726)\end{array}$ \\
\hline Upper secondary & & $\begin{array}{c}4.472 \\
(8.165)\end{array}$ & & & $\begin{array}{c}3.431 \\
(6.923)\end{array}$ \\
\hline Post-secondary (non-degree) & & $\begin{array}{c}7.177 \\
(8.322)\end{array}$ & & & $\begin{array}{c}4.279 \\
(7.111)\end{array}$ \\
\hline Post-secondary (degree) & & $\begin{array}{c}2.584 \\
(8.280)\end{array}$ & & & $\begin{array}{c}1.205 \\
(7.028)\end{array}$ \\
\hline \multicolumn{6}{|l|}{ Residence (baseline: E. Kowloon) } \\
\hline E. New Territories & & $\begin{array}{c}-1.703 \\
(2.069)\end{array}$ & & & $\begin{array}{c}-0.116 \\
(2.134)\end{array}$ \\
\hline Hong Kong Island & & $\begin{array}{c}3.105 \\
(2.195)\end{array}$ & & & $\begin{array}{c}3.419 \\
(2.265)\end{array}$ \\
\hline W. Kowloon & & $\begin{array}{c}-0.409 \\
(2.198)\end{array}$ & & & $\begin{array}{c}-0.590 \\
(2.217)\end{array}$ \\
\hline W. New Territories & & $\begin{array}{c}-0.317 \\
(2.007)\end{array}$ & & & $\begin{array}{c}0.729 \\
(2.112)\end{array}$ \\
\hline \multicolumn{6}{|l|}{ Class (baseline: upper) } \\
\hline Upper middle & & $\begin{array}{c}0.140 \\
(1.591)\end{array}$ & & & $\begin{array}{c}0.104 \\
(1.592)\end{array}$ \\
\hline Middle & & $\begin{array}{l}4.639^{\star \star} \\
(1.827)\end{array}$ & & & $\begin{array}{c}2.904 \\
(1.857)\end{array}$ \\
\hline Lower middle & & $\begin{array}{c}4.334 \\
(3.587)\end{array}$ & & & $\begin{array}{c}2.088 \\
(3.488)\end{array}$ \\
\hline Lower & & $\begin{array}{c}6.662 \\
(7.031)\end{array}$ & & & $\begin{array}{c}4.944 \\
(6.678)\end{array}$ \\
\hline \multicolumn{6}{|c|}{ Occupation (baseline: clerical and service worker) } \\
\hline Executive and professional & & $\begin{array}{c}-1.095 \\
(1.556)\end{array}$ & & & $\begin{array}{c}-0.0782 \\
(1.556)\end{array}$ \\
\hline Homemaker/housewife & & $\begin{array}{c}-3.751 \\
(4.016)\end{array}$ & & & $\begin{array}{c}-3.703 \\
(4.419)\end{array}$ \\
\hline Others & & $\begin{array}{c}-0.782 \\
(4.537)\end{array}$ & & & $\begin{array}{c}-0.00962 \\
(4.603)\end{array}$ \\
\hline Production worker & & 1.617 & & & $\begin{array}{c}0.270 \\
\text { (Continued) }\end{array}$ \\
\hline
\end{tabular}


Table 2. (Continued.)

\begin{tabular}{|c|c|c|c|c|c|}
\hline Variables & BASELINE (1) & DEMOGR (2) & $\mathrm{DQ}(3)$ & ECON (4) & FULL (5) \\
\hline & & (2.711) & & & $(2.735)$ \\
\hline \multirow[t]{2}{*}{ Retired } & & 1.999 & & & -0.280 \\
\hline & & (3.910) & & & $(3.842)$ \\
\hline \multirow[t]{2}{*}{ Student } & & 5.137 & & & $5.960^{\star}$ \\
\hline & & (3.384) & & & $(3.512)$ \\
\hline \multirow[t]{2}{*}{ Unemployed } & & 3.973 & & & 3.421 \\
\hline & & (3.698) & & & (3.413) \\
\hline \multirow[t]{2}{*}{ Constant } & $30.40^{\star \star \star}$ & 9.484 & $44.26^{\star \star \star}$ & $51.35^{\star \star \star}$ & $49.58^{\star \star \star}$ \\
\hline & $(1.710)$ & (9.024) & $(2.471)$ & (3.142) & $(8.846)$ \\
\hline Observations & 2,111 & 2,035 & 2,021 & 1,967 & 1,778 \\
\hline$R^{2}$ & 0.197 & 0.230 & 0.230 & 0.237 & 0.333 \\
\hline
\end{tabular}

Robust standard errors in parentheses. ${ }^{\star * \star} P<0.01,{ }^{\star \star} P<0.05,{ }^{\star} P<0.1$.

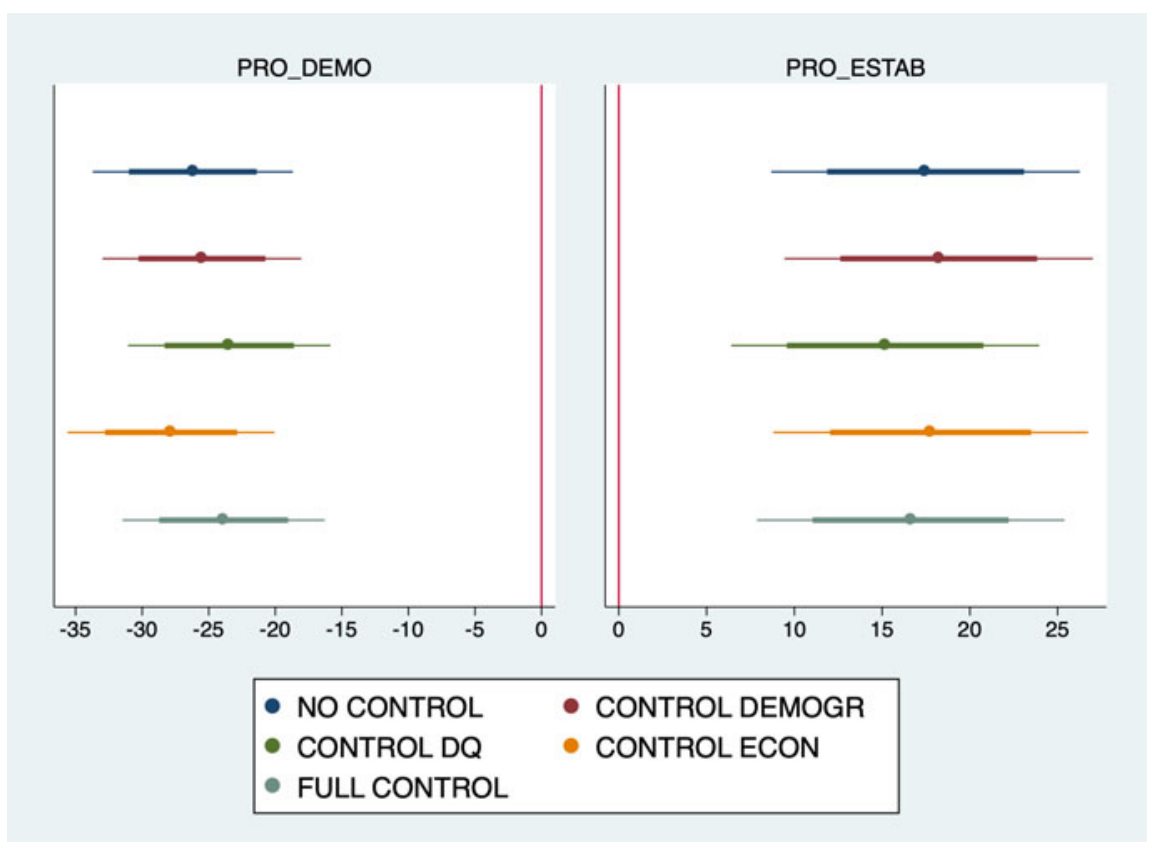

Figure 1. NSL's effects on institutional trust by political stances: ACGT.

patterns that the respondents who trusted the Central Government more tended to be those who had lower expectations of Hong Kong's economic prospect, social welfare provision, and DQ incidents (models (3)-(5)).

The results above help further enrich the literature on how protests and their repression affect public opinions because they not only extend it to the case of Hong Kong, but also paint a more complete picture through the effect heterogeneities our analyses identify. On the one hand, our results about the NSL's effects on one's institutional trust partially echo Sangnier and Zylberberg's (2017) study in Africa in finding the plunge in trust among pro-democracy Hong Kongers during the post-repression (NSL) period. On the other hand, despite through a different theoretical mechanism, the surge of institutional trust among the pro-establishment camp is consistent with Frye and Borisova's (2019) finding that the information about unexpected protests can positively update Russian citizens' perceptions of the government trustworthiness. 
Table 3. Protest repertoire

\begin{tabular}{ll}
\hline Variable name & \multicolumn{1}{c}{ Repertoire } \\
\hline Demonstration & Demonstrations, rallies \\
Yellow & Yellow economic circle (patronize yellow shops; boycott blue ones) \\
Chanting & Shop with you (wander around and chant slogans at shopping malls) \\
Vandalism & 'Renovate' (vandalize blue or anti-protest shops) \\
Vigilante & Vigilantism (violently attack anti-protest people) \\
Help & Others (assisting newly-elected district council members, advertising, \\
& facilitating international promotion) \\
\hline
\end{tabular}

\subsection{Protest expectations}

As two recent related studies on Egypt (El-Mallakh, 2020) and Russia (Tertytchnaya and Lankina, 2020) show, people became more inclined to value order and stability after their exposure to protests and repression. In the context of our current study, this implies that one's institutional trust might actually go up if he or she had a stronger belief in the NSL's ability to rein in protest mobilization and dampen the social support for the Movement. In other words, this introduces another layer of effect heterogeneity through which the NSL affected one's institutional trust. The following question in our second survey allowed us to investigate this question and further unpack the relationship between the NSL and one's institutional trust in Hong Kong:

How would you rate the probability for the NSL to calm the Anti-ELAB Movement that broke out in June last year (2019)?

Respondents were then presented with an 11-grade scale on which a larger number denoted a higher probability. A dummy variable of protest expectation, $\mathrm{CA}$, was constructed with responses higher than its average (3.79) designated as low expectations $(\mathrm{CA}=0)$ and otherwise as high ones $(\mathrm{CA}=1)$.

Before reporting the estimation of CA's effects on institutional trust, we show below how CA as a summary measure of one's overall protest expectation does co-vary with his or her assessments for individual protest forms. During the second half of 2019, we had witnessed several of the Hong Kong protesters used to vent, either peacefully or violently, their anger and grievances. Table 3 provides a comprehensive summary (and the variable names we used in the regressions).

To see if one's protest expectation measured by CA was correlated with the full gamut of protest repertoire as predicted, we regressed the former on respondents' likelihood assessment (on an 11-grade scale) for each form of the latter adopted by ordinary citizens and protesters, respectively (see Appendix C for more details about how we constructed the variables), and the results illustrated in Figure 2 show exactly that.

That is, despite different extents, across all the protest forms and for both citizens and protesters, the less one expected the NSL to rein in the intensity of the Movement, the more likely he or she would expect any one of the protest forms to take place. These results not only make us reassured about the internal validity of CA as a measure of one's overall protest expectation, but also reveal that the protest optimists expected more peaceful protest forms to transpire - i.e., Chanting, Help, and, Yellow.

There are two major findings from our regressional analyses - based on the estimation frameworks (4) and (5) - that highlight our key contributions to the literature. First of all, Figure 3 illustrates the linear predictions of first-differenced institutional trust based on the stance-specific estimates for average Central Government institutions from Table 4 (model (1) baseline). The findings show that, regardless of one's political stance, a greater protest expectation, or a weaker belief in the NSL's stabilizing effect, was associated with a greater decrease in institutional trust. Counterintuitively, even for pro-democracy respondents, while the NSL had substantially reduced their institutional trust, the degree of the reduction however was smaller among the democrats who had stronger beliefs

\footnotetext{
${ }^{19}$ In the color politics of the Anti-ELAB Movement, 'yellow' was used to label those (politicians, shop owners, opinion leaders, etc.) who sympathized with the Movement, while 'blue' used for those who disapproved of it.
} 


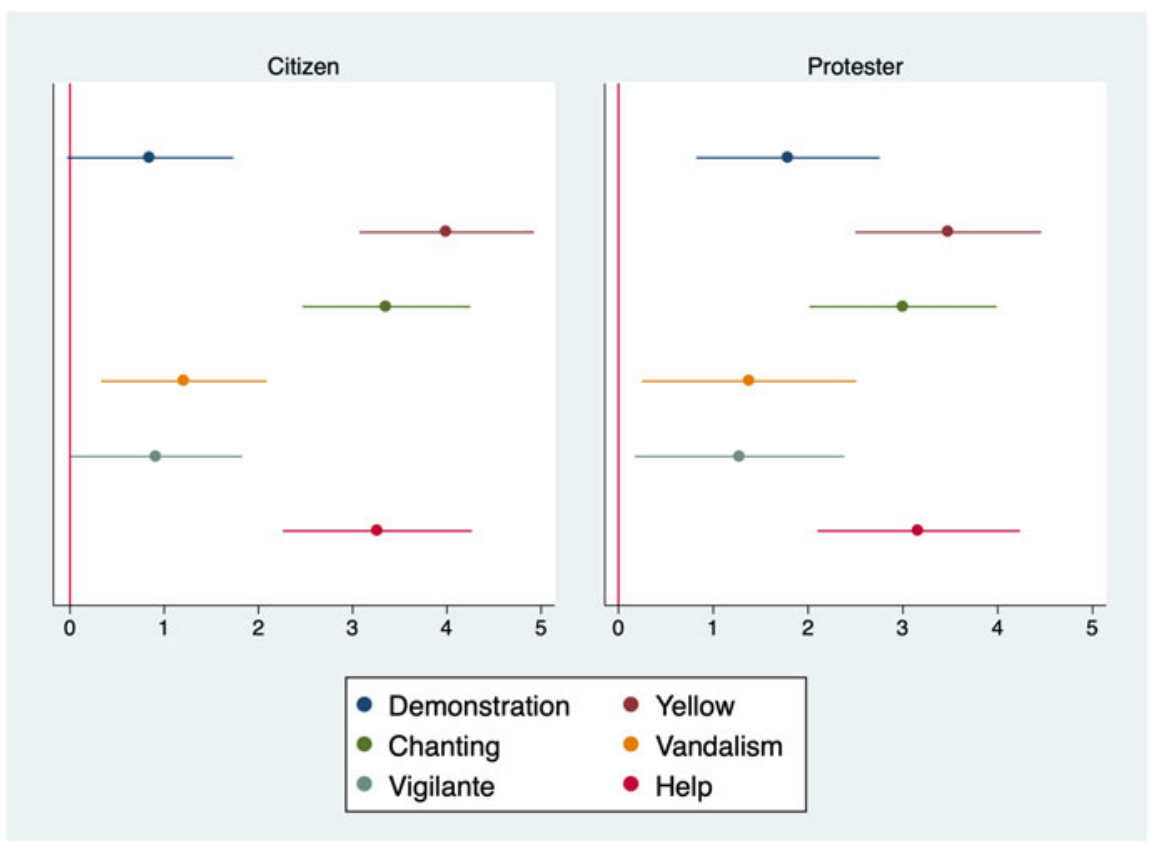

Figure 2. Protest expectations and repertoire.

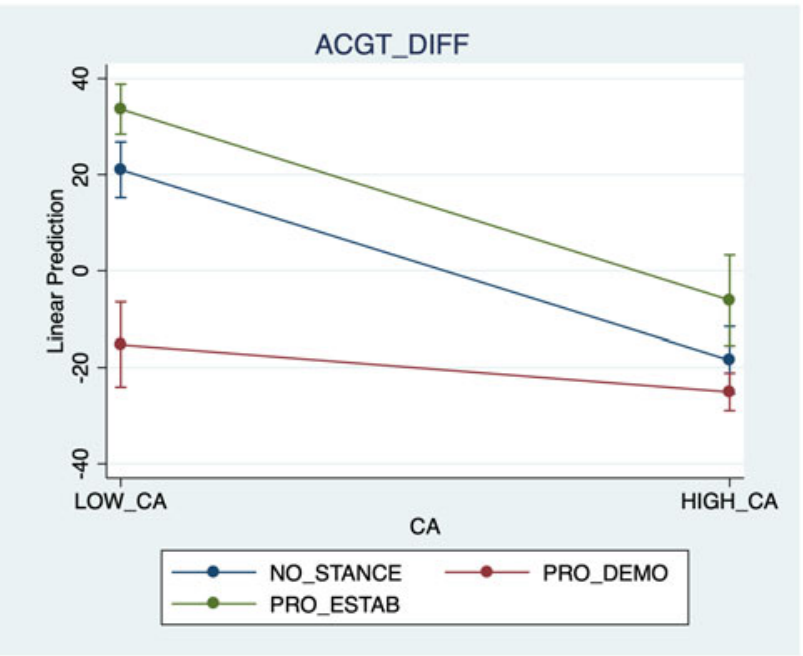

Figure 3. Stance-wise predicted margins by protest expectations: ACGT.

in the NSL's ability to restore social order and lower protest expectations. While this conclusion doesn't carry as much casual significance as the previous analyses on the NSL, it confirms our informational hypothesis that the lower the protest expectation one has, the smaller the decrease in his or her institutional trust will be. It also echoes El-Mallakh's (2020) and Tertytchnaya and Lankina's (2020) arguments about the post-protest crave for stability and we show it here that this desire is also positively associated with institutional trust. ${ }^{20}$

\footnotetext{
${ }^{20}$ What should be kept in mind is that, since the findings are only correlational, it is also likely that those who had highinstitutional trusts showed stronger confidence in the NSL's stabilizing effects. Our data limitation makes it impossible to make a causal inference on this part of the results, but it is surprising enough to find such a correlation.
} 
Table 4. Protest expectations and first-differenced institutional trust: ACGT

\begin{tabular}{|c|c|c|c|c|}
\hline Variables & BASELINE (1) & DQ (2) & ECON (3) & FULL (4) \\
\hline $\mathrm{CA}$ & $\begin{array}{c}-39.49^{\star \star \star} \\
(4.607)\end{array}$ & $\begin{array}{c}-35.48^{\star \star \star} \\
(4.757)\end{array}$ & $\begin{array}{c}-39.00^{\star \star \star} \\
(4.901)\end{array}$ & $\begin{array}{c}-40.01^{\star \star \star} \\
(4.400)\end{array}$ \\
\hline PRO_DEMO & $\begin{array}{c}-36.27^{\star \star \star} \\
(5.373)\end{array}$ & $\begin{array}{c}-33.41^{\star \star *} \\
(5.468)\end{array}$ & $\begin{array}{c}-37.97^{\star \star \star} \\
(5.580)\end{array}$ & $\begin{array}{c}-38.78^{\star \star \star} \\
(5.365)\end{array}$ \\
\hline PRO_ESTAB & $\begin{array}{l}12.62^{\star \star \star} \\
(3.965)\end{array}$ & $\begin{array}{l}11.47^{\star \star \star} \\
(4.109)\end{array}$ & $\begin{array}{l}15.42^{\star \star \star} \\
(4.114)\end{array}$ & $\begin{array}{l}14.66^{\star * \star} \\
(4.025)\end{array}$ \\
\hline CA ×PRO_DEMO & $\begin{array}{c}29.69^{\star \star \star} \\
(6.734)\end{array}$ & $\begin{array}{c}27.55^{\star \star \star} \\
(6.799)\end{array}$ & $\begin{array}{l}29.80^{\star \star \star} \\
(7.105)\end{array}$ & $\begin{array}{l}32.73^{\star \star \star} \\
(6.472)\end{array}$ \\
\hline CA $\times$ PRO_ESTAB & $\begin{array}{c}-0.233 \\
(7.154)\end{array}$ & $\begin{array}{c}-3.841 \\
(7.380)\end{array}$ & $\begin{array}{c}-5.420 \\
(7.599)\end{array}$ & $\begin{array}{c}-4.658 \\
(7.158)\end{array}$ \\
\hline DQ_OPM_DIFF & & $\begin{array}{c}-0.168^{\star \star \star} \\
(0.0371)\end{array}$ & & $\begin{array}{r}-0.0619^{\star} \\
(0.0357)\end{array}$ \\
\hline HKECON_DIFF & & & $\begin{array}{c}-0.0546 \\
(1.495)\end{array}$ & $\begin{array}{c}-1.587 \\
(1.500)\end{array}$ \\
\hline WEL_EXP_DIFF & & & $\begin{array}{l}-8.120^{\star \star \star *} \\
(1.196)\end{array}$ & $\begin{array}{c}-6.325^{\star \star \star} \\
(1.137)\end{array}$ \\
\hline PRO_DEMO_PRE & & & & $\begin{array}{l}24.28^{\star \star \star} \\
(2.837)\end{array}$ \\
\hline PRO_ESTAB_PRE & & & & $\begin{array}{c}-16.20^{\star \star \star} \\
(3.309)\end{array}$ \\
\hline Constant & $\begin{array}{l}21.01^{\star \star \star} \\
(2.948)\end{array}$ & $\begin{array}{l}19.65^{\star \star \star} \\
(3.102)\end{array}$ & $\begin{array}{c}23.63^{\star \star \star} \\
(4.051)\end{array}$ & $\begin{array}{l}21.04^{\star \star \star} \\
(4.566)\end{array}$ \\
\hline Observations & 1,004 & 924 & 862 & 788 \\
\hline$R^{2}$ & 0.285 & 0.291 & 0.332 & 0.460 \\
\hline
\end{tabular}

Robust standard errors in parentheses.

${ }^{* *} P<0.01,{ }^{* *} P<0.05,{ }^{*} P<0.1$.

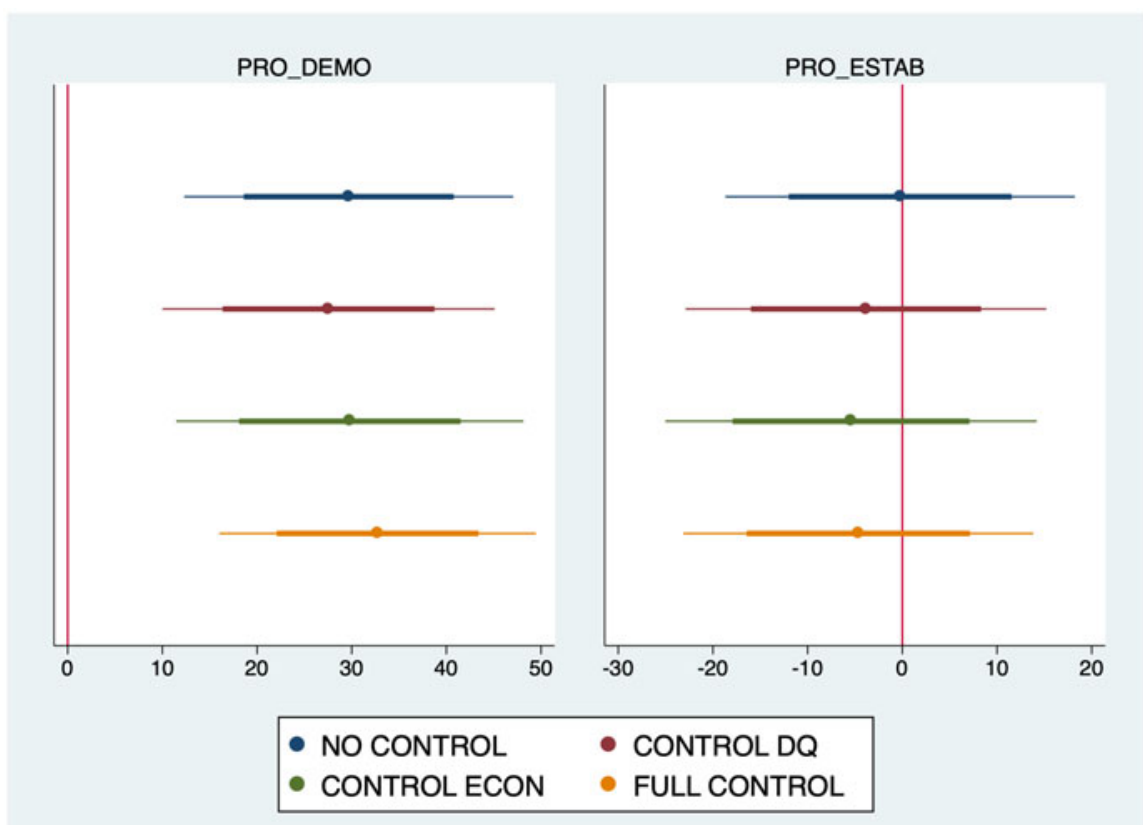

Figure 4. Protest expectations and first-differenced institutional trust: ACGT. 
Second, while a lower protest expectation is associated with a greater increase in institutional trust for all political stances, the effect is however heterogeneous across them. First of all, using the no-stancers as the baseline, Figure 4 visualizes CA's marginal effects (the coefficients of the interaction terms in Table 4) on the difference between one's pre- and post-NSL average trust for Central Government institutions for pro-democracy and pro-establishment camps, respectively. As it shows, the differences in the increase in institutional trust between no-stancers and pro-establishmentarians are statistically ignorable. In contrast, among pro-democracy respondents, as their protest expectations get lower, the corresponding upward shifts in their institutional trusts are, however, substantially smaller in magnitude than those of other stances. From the informational perspective proposed above, this effect heterogeneity implies that democrats as self-perceived outcasts of authoritarian institutions didn't update their institutional beliefs with the NSL's shock on protesters' mobilization as much as self-perceived regime insiders. $^{21}$

Finally, we also conducted a series of robustness tests for CA (models (2)-(4) in Table 4) - except that no demographic variables were added since they were exactly the same given a very short span between the two surveys. The results above were proven very stable and robust to more controls of respondents' other political as well as economic attitudes, pre-NSL political stances, and CA's original 11-grade scale. ${ }^{22}$

\subsection{Hong Kong's local institutions}

As a supplement to the main results above, we investigate in this section whether the NSL and Hong Kongers' protest expectations also affected their trust in Hong Kong's local institutions included in this study - i.e., the Chief Executive (CE), the Court, the LegCo, the Police (POL), the Registration, and Electoral Office (REO). First and foremost, according to Table 5 and Figure 5, although to somewhat different degrees, the NSL's heterogeneous effects among political stances were also present in Hong Kongers' trust in all of them and the polarizing trend between democrats and pro-establishmentarians was especially salient among the local executive institutions. While the former's institutional trust in the Chief Executive and the Police was slashed by the NSL by roughly $20 \%$, it nonetheless went up by a similar magnitude among the latter.

In contrast, the trend was less obvious for the local monitoring institutions à la Sangnier and Zylberberg (2017). First of all, while the direction of each effect remained unchanged for both stances, the magnitude of the difference between them shrank by half to $10 \%$ for the Registration and Electoral Office. Second, as far as the Court and the LegCo are concerned, the effect sizes were further reduced to digit numbers. In other words, the NSL's effect varied not only among political stances, but also among institutions. As far as the Court is concerned, this contrast is not surprising. Despite the aforementioned controversy about NPCSC's power of final interpretation, Hong Kong's Court is clearly the quintessential element of the common law tradition left from the colonial period and a crucial pillar of the rule of law, which has also become an integral part of Hong Kongers' political identity (Chan and Chan, 2006). Finally, the results presented above are also very robust to different model specifications when we added more controls including respondents' demographics, other political and economic attitudes, and pre-NSL political stances (see Tables D.11-D.14 in Appendix D.3.1 for more details).

As for the effects of one's protest expectation (CA), Figure 6 again visualizes its stance-wise linear predictions of first-differenced institutional trust for the same set of local institutions in Hong Kong based on the regression estimates in Table 6. Just as what we have found for the Central Government trust above, the results are also consistent with our informational hypothesis that, for all political

\footnotetext{
${ }^{21}$ While it might appear in Figure 4 that the effect sizes are larger among pro-democracy respondents, it should be noted that CA's stance-specific effect for each institution is the summation of this marginal effect and the baseline effect (i.e., CA's coefficient in Table 4).

${ }^{22}$ See Tables D.6-D.9 and Figure D.1 in Appendix D.2 for the linear prediction plots and regression results for individual Central Government institutions. Moreover, the regression results with CA as a continuous measure are also documented in Table D.10 in the same section.
} 
Table 5. NSL's effects on institutional trust: Hong Kong's local institutions

\begin{tabular}{|c|c|c|c|c|c|}
\hline Variables & $\begin{array}{c}(1) \\
\text { TRUST_CE }\end{array}$ & $\begin{array}{c}\text { (2) } \\
\text { TRUST_COURT }\end{array}$ & $\begin{array}{c}\text { (3) } \\
\text { TRUST_LEGCO }\end{array}$ & $\begin{array}{c}(4) \\
\text { TRUST_REO }\end{array}$ & $\begin{array}{c}(5) \\
\text { TRUST_POL }\end{array}$ \\
\hline NSL & $\begin{array}{l}6.129^{\star \star \star} \\
(2.146)\end{array}$ & $\begin{array}{r}3.816^{*} \\
(1.975)\end{array}$ & $\begin{array}{c}-1.245 \\
(1.664)\end{array}$ & $\begin{array}{l}3.640^{*} \\
(2.031)\end{array}$ & $\begin{array}{l}5.674^{\star \star} \\
(2.458)\end{array}$ \\
\hline PRO_DEMO & $\begin{array}{c}-0.345 \\
(2.038)\end{array}$ & $\begin{array}{c}-1.175 \\
(1.911)\end{array}$ & $\begin{array}{r}-1.133 \\
(1.619)\end{array}$ & $\begin{array}{c}-0.541 \\
(1.931)\end{array}$ & $\begin{array}{c}-3.025 \\
(2.404)\end{array}$ \\
\hline PRO_ESTAB & $\begin{array}{c}2.272 \\
(2.326)\end{array}$ & $\begin{array}{c}0.401 \\
(2.116)\end{array}$ & $\begin{array}{c}0.134 \\
(1.778)\end{array}$ & $\begin{array}{c}2.356 \\
(2.134)\end{array}$ & $\begin{array}{c}-1.313 \\
(2.686)\end{array}$ \\
\hline NSL × PRO_DEMO & $\begin{array}{c}-24.21^{\star \star \star} \\
(2.638)\end{array}$ & $\begin{array}{l}-8.079^{\star \star *} \\
(2.630)\end{array}$ & $\begin{array}{r}-3.750^{\star} \\
(2.231)\end{array}$ & $\begin{array}{c}-15.30^{\star \star *} \\
(2.646)\end{array}$ & $\begin{array}{c}-27.10^{\star \star *} \\
(3.032)\end{array}$ \\
\hline NSL $\times$ PRO_ESTAB & $\begin{array}{l}12.41^{\star \star \star} \\
(3.175)\end{array}$ & $\begin{array}{c}1.553 \\
(2.850)\end{array}$ & $\begin{array}{l}7.921^{\star \star \star} \\
(2.488)\end{array}$ & $\begin{array}{l}7.108^{\star \star} \\
(2.952)\end{array}$ & $\begin{array}{l}18.56^{\star \star \star} \\
(3.602)\end{array}$ \\
\hline Constant & $\begin{array}{l}25.37^{\star \star \star} \\
(1.531)\end{array}$ & $\begin{array}{l}48.70^{\star \star \star} \\
(1.462)\end{array}$ & $\begin{array}{c}31.38^{\star \star \star} \\
(1.217)\end{array}$ & $\begin{array}{c}36.39^{\star \star \star} \\
(1.479)\end{array}$ & $\begin{array}{c}32.50^{\star \star \star} \\
(1.819)\end{array}$ \\
\hline Observations & 2,215 & 2,284 & 2,230 & 2,209 & 2,203 \\
\hline$R^{2}$ & 0.170 & 0.019 & 0.028 & 0.080 & 0.188 \\
\hline
\end{tabular}

Robust standard errors in parentheses.

${ }^{\star \star \star} P<0.01,{ }^{\star \star} P<0.05,{ }^{\star} P<0.1$.

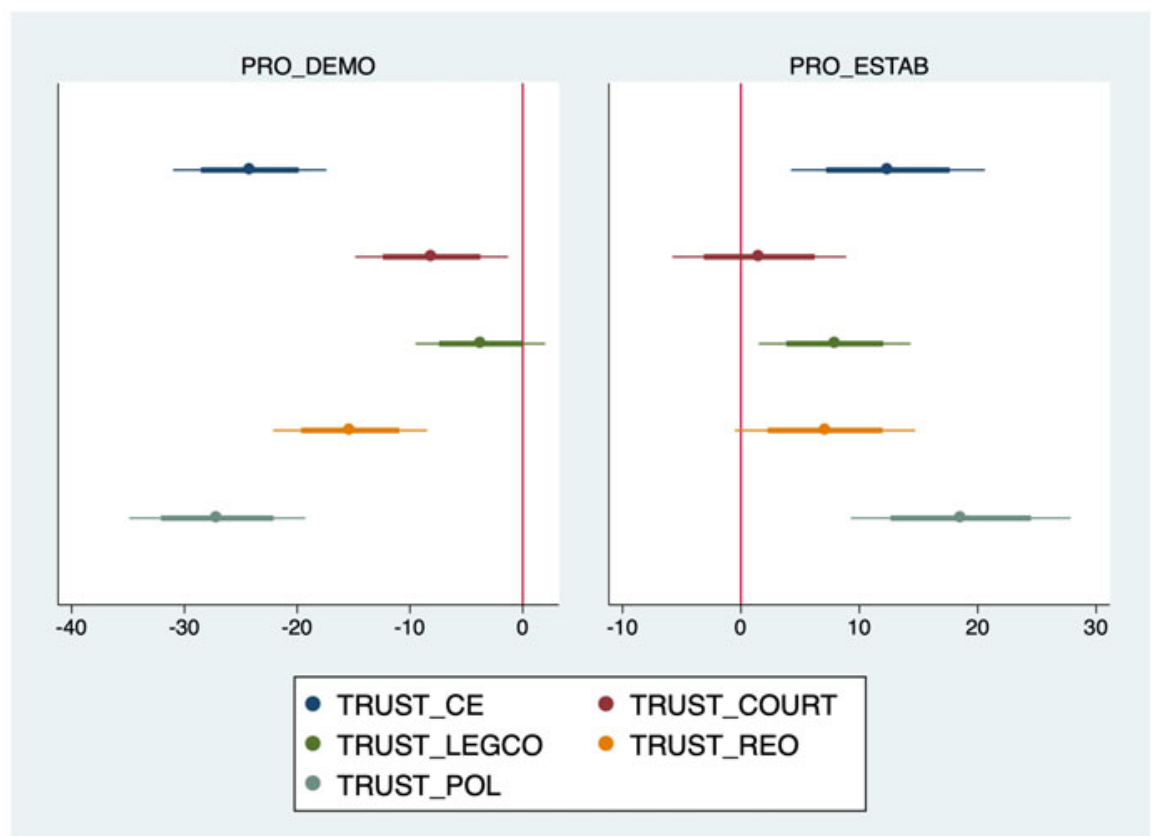

Thick and thin lines are $90 \%$ and $95 \%$ confidence intervals, respectively.

Figure 5. NSL's effects on institutional trust by political stances: Hong Kong's local institutions.

stances, a higher expectation of future protests is associated with a lower level of institutional trust for all the local institutions across the board. ${ }^{23}$

\footnotetext{
${ }^{23}$ What is worth noting here is that the effect of pro-establishment respondents' protest expectations on their firstdifferenced trust in the Court is substantially smaller than other institutions. Based on the estimates in Table 6, while the difference is still statistically significant, a higher expectation of protest is only associated roughly with a $1 \%$ reduction in the trust in the Court among pro-establishmentarians.
} 
(a) Chief Executive

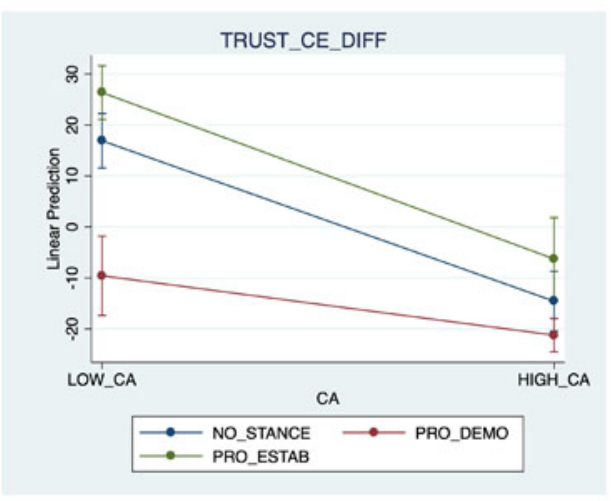

(c) Legislative Council

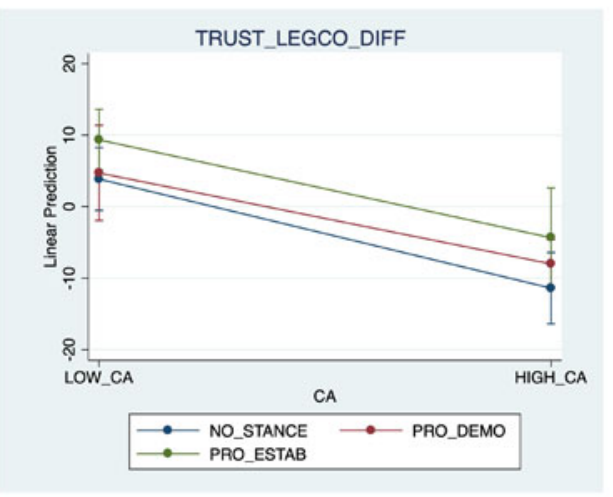

(b) Court

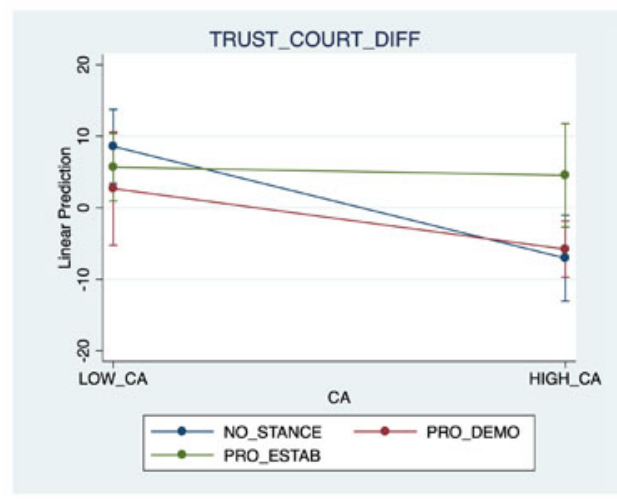

(d) Police

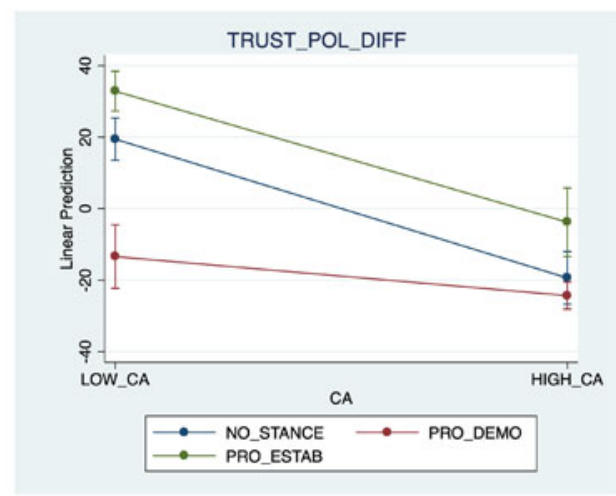

(e) Registration and Electoral Office

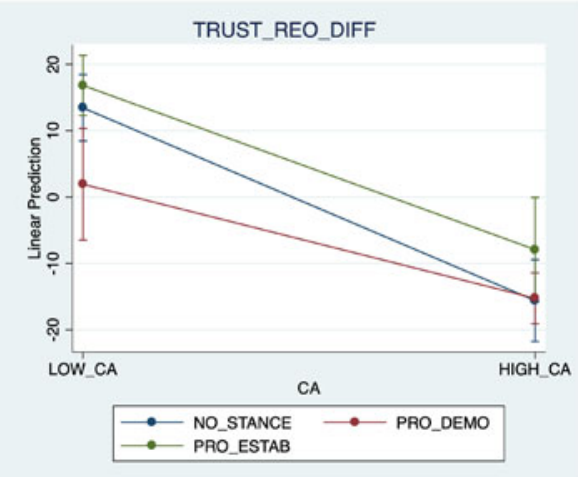

Figure 6. Stance-wise predicted margins by protest expectations: Hong Kong's local institutions.

Moreover, we also gained new insights from delving into CA's stance-specific marginal effects. First of all, as Figure 7 demonstrates, we did find the same kind of effect heterogeneity among political stances for Hong Kong's local institutions. Compared to no-stancers and pro-establishmentarians, CA's negative effect on one's institutional trust was dampened among democrats. Moreover, among pro-democracy respondents, there existed another effect heterogeneity between the monitoring i.e., the Court, the LegCo, and the Registration and Electoral Office - and the executive institutions 
Table 6. Protest expectations and first-differenced institutional trust: Hong Kong's local institutions

\begin{tabular}{|c|c|c|c|c|c|}
\hline Variables & $\begin{array}{c}(1) \\
\text { TRUST_CE_DIFF }\end{array}$ & $\begin{array}{c}(2) \\
\text { TRUST_COURT_DIFF }\end{array}$ & $\begin{array}{c}(3) \\
\text { TRUST_LEGCO_DIFF }\end{array}$ & $\begin{array}{c}\text { (4) } \\
\text { TRUST_REO_DIFF }\end{array}$ & $\begin{array}{c}(5) \\
\text { TRUST_POL_DIFF }\end{array}$ \\
\hline CA & $\begin{array}{c}-31.48^{\star \star \star} \\
(4.039)\end{array}$ & $\begin{array}{c}-15.62^{\star \star \star} \\
(4.037)\end{array}$ & $\begin{array}{c}-15.26^{\star \star \star} \\
(3.389)\end{array}$ & $\begin{array}{c}-29.07^{\star \star \star} \\
(4.048)\end{array}$ & $\begin{array}{c}-38.83^{\star \star \star} \\
(4.810)\end{array}$ \\
\hline PRO_DEMO & $\begin{array}{c}-26.48^{\star \star \star} \\
(4.802)\end{array}$ & $\begin{array}{c}-5.894 \\
(4.820)\end{array}$ & $\begin{array}{c}0.852 \\
(4.068)\end{array}$ & $\begin{array}{r}-11.53^{\star \star} \\
(4.989)\end{array}$ & $\begin{array}{c}-32.87^{\star \star \star \star} \\
(5.438)\end{array}$ \\
\hline PRO_ETAB & $\begin{array}{l}9.456^{\star \star} \\
(3.820)\end{array}$ & $\begin{array}{c}-2.910 \\
(3.566)\end{array}$ & $\begin{array}{c}5.482^{\star} \\
(3.121)\end{array}$ & $\begin{array}{c}3.381 \\
(3.444)\end{array}$ & $\begin{array}{l}13.42^{\star \star \star} \\
(4.131)\end{array}$ \\
\hline CA $\times$ PRO_DEMO & $\begin{array}{l}19.82^{\star \star \star} \\
(5.897)\end{array}$ & $\begin{array}{l}7.144 \\
(6.048)\end{array}$ & $\begin{array}{c}2.538 \\
(5.095)\end{array}$ & $\begin{array}{l}11.87^{\star} \\
(6.212)\end{array}$ & $\begin{array}{c}27.94^{\star \star \star *} \\
(6.889)\end{array}$ \\
\hline CA $\times$ PRO_ESTAB & $\begin{array}{c}-1.154 \\
(6.370)\end{array}$ & $\begin{array}{r}14.49^{\star *} \\
(5.971)\end{array}$ & $\begin{array}{c}1.575 \\
(5.367)\end{array}$ & $\begin{array}{c}4.313 \\
(6.142)\end{array}$ & $\begin{array}{c}2.175 \\
(7.422)\end{array}$ \\
\hline Constant & $\begin{array}{l}16.91^{\star \star \star} \\
(2.719)\end{array}$ & $\begin{array}{l}8.584^{\star * \star} \\
(2.632)\end{array}$ & $\begin{array}{l}3.863^{*} \\
(2.239)\end{array}$ & $\begin{array}{l}13.46^{\star \star \star} \\
(2.553)\end{array}$ & $\begin{array}{l}19.44^{\star \star *} \\
(3.002)\end{array}$ \\
\hline Observations & 1,017 & 1,082 & 1,033 & 1,016 & 1,006 \\
\hline$R^{2}$ & 0.238 & 0.028 & 0.057 & 0.140 & 0.264 \\
\hline
\end{tabular}

Robust standard errors in parentheses.

${ }^{\star \star \star} P<0.01,{ }^{\star \star} P<0.05,{ }^{\star} P<0.1$.

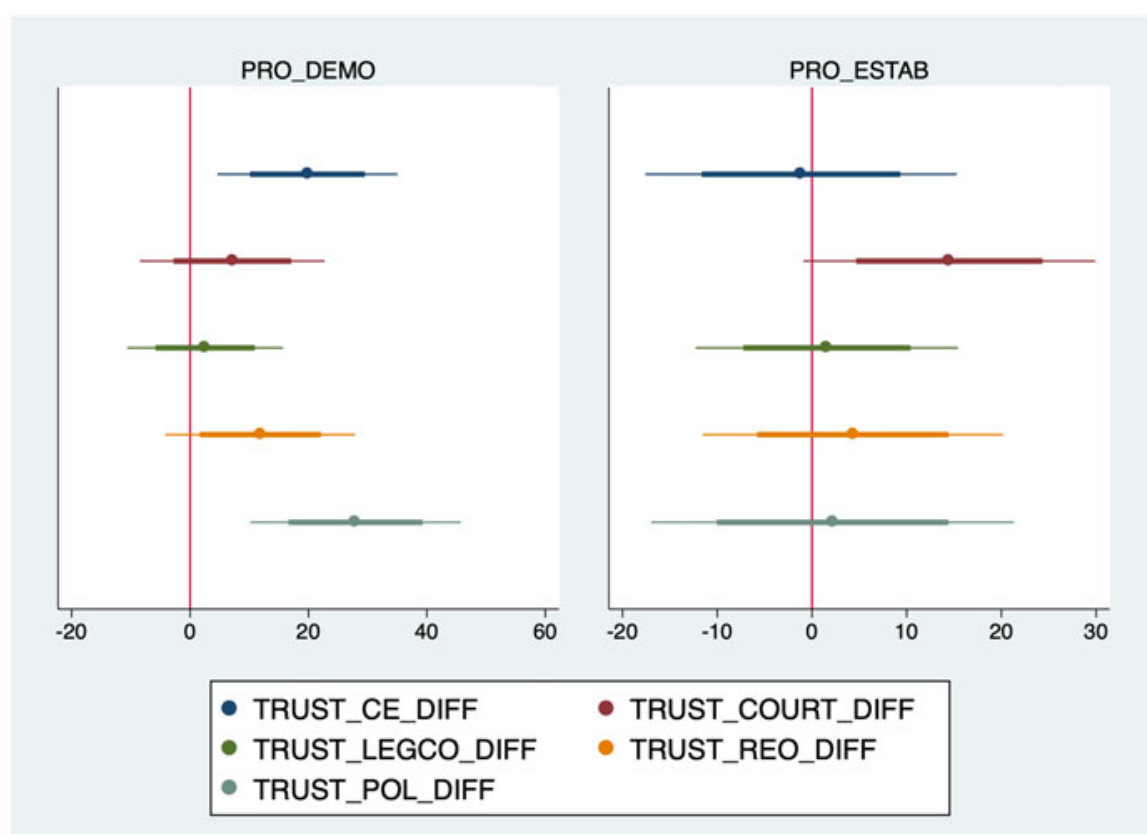

Thick and thin lines are $90 \%$ and $95 \%$ confidence intervals, respectively.

Figure 7. Protest expectations and first-differenced institutional trust: Hong Kong's local institutions.

- i.e., the Chief Executive and the Police. As Figure 7 shows, compared to no-stancers, the (dampening) effect a democrat's protest expectation induces is smaller for the former vis-á-vis is the latter. Based on the same informational perspective, this implies that the CA-related belief for a particular institution to remain relatively unaffected in the post-NSL era was substantially stronger regarding the monitoring ones as opposed to the others, and therefore allowed the former to retain trust 


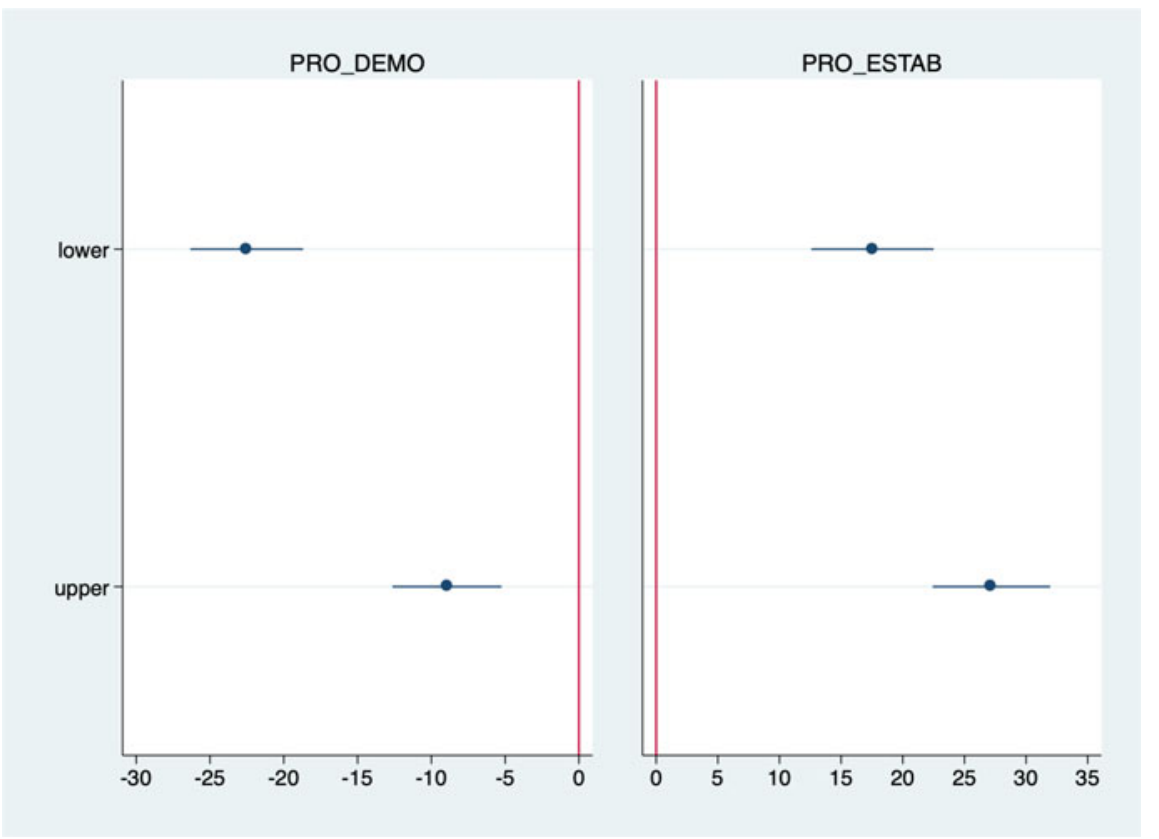

Figure 8. Treatment-effect bounds: ACGT.

when people expected fewer protests to transpire. Finally, these results are also very robust to different model specifications (see Tables D.15-D.17 in Appendix D.3.2 for more details).

Combined, the two effect heterogeneities presented above help shed light on Hong Kong's post-NSL political landscape. On the one hand, it echoes Rozenas and Zhukov (2019) that the regime support - either institutional trust or loyalty - under dictatorships is closely related to the regime's credibility in suppressing political dissent. Moreover, this effect is dampened when the regime inclusiveness is low. On the other hand, while there was clearly an NSL-induced bifurcation in the trust in the executive institutions between pro-democracy and pro-establishment Hong Kongers, both camps, however, still shared in common similar levels of trust in monitoring institutions.

\subsection{Robustness checks}

We report more tests in this section ${ }^{24}$ to make sure our results are robust not only to different sets of controls, but also to other potential issues that might bias our empirical estimations.

\subsubsection{Attrition and data censoring}

We first address two sample-related issues. To begin with, despite our low attrition rate of roughly $10 \%$, the fact that the NSL could affect the first-round respondents' decisions to accept or reject our second survey invitation might introduce a selection bias and make the sample nonrandom with respect to the NSL as an external shock. To address this issue, we adopted Lee (2009) bounds estimator that estimates an interval for the true value of the treatment effect in the presence of nonrandom sample selection. As Figure 8 shows, we obtain fairly narrow estimated treatment-effect bounds for the ACGT - -9 to -24 for pro-democracy and 17-27 for pro-establishment Hong Kongers. While the former implies that our baseline model (model (1) in Table 2) slightly overestimates (in the absolute sense) the magnitude of the NSL effect among democrats, the Lee-bounds

\footnotetext{
${ }^{24}$ To save space, we leave other robustness checks on issues of sample re-weighting and non-responses (self-censorship) in Appendices E.4 and E.5.
} 


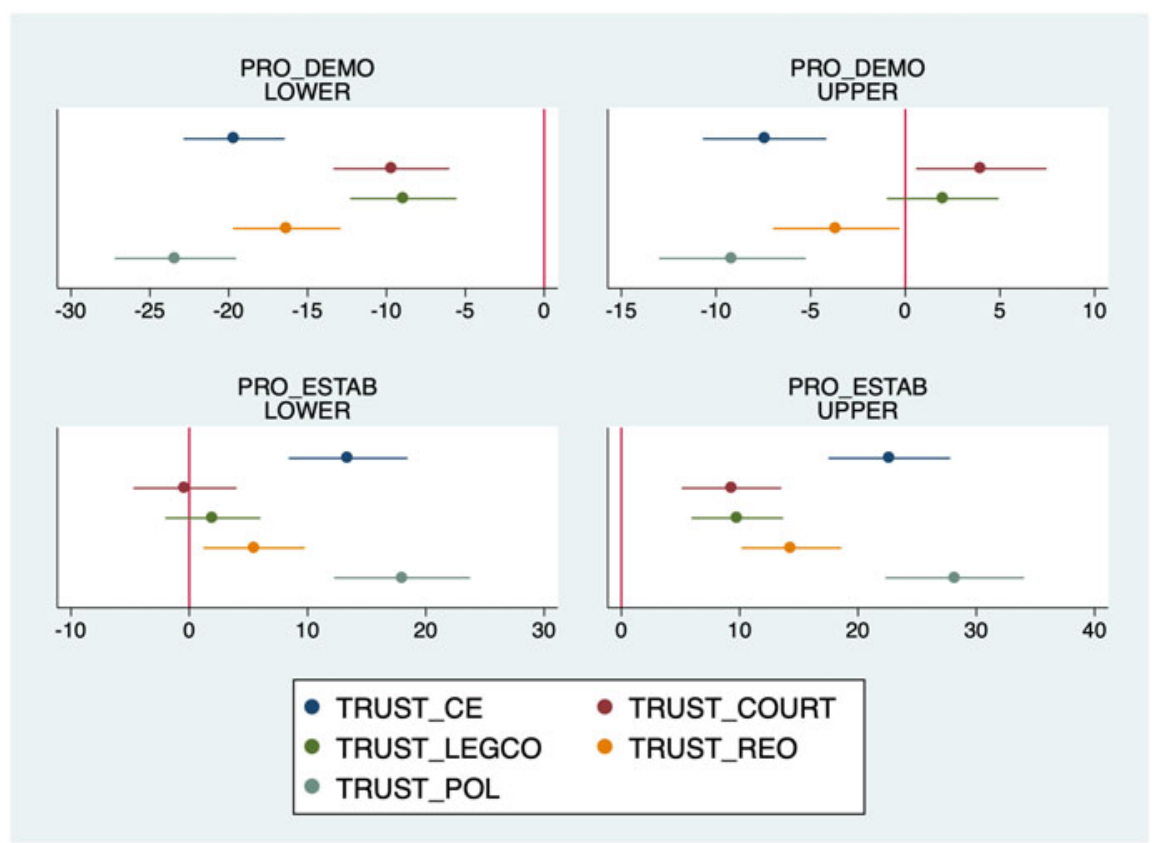

Figure 9. Treatment-effect bounds: Hong Kong's local institutions.

estimator still confirms the robustness of the directions and statistical significance of the hypothesized NSL effects across all political stances. ${ }^{25}$

Moreover, Figure 9 presents the estimated Lee bounds of the NSL effects for Hong Kong's local institutions respectively. On the one hand, the majority of the baseline estimates in Table 5 fall within the estimated bounds except those for democrats' institutional trust in the Chief Executive and the Police that slightly exceed the lower bounds.

In addition, estimating the effects of the NSL on institutional trust critically depends on comparing one's choices over trust levels between the two surveys. Naturally, while they were independently administered, the size of the difference for some respondents might, however, be artificially limited by the choice range provided to them in the second round. For example, for one who already rated a given institution very low (high) during the first round, the fact that the range of values to be chosen was bounded by 0 (100) from below (above) had artificially forced the difference between his or her pre- and post-NSL trust levels to be smaller than it could have been if the lower (upper) bound was absent. In other words, the way in which our questionnaire was designed censored our dependent variable from both above and below, and this could bias our results. To address this second issue in our sample, we re-estimated them by running Tobit models with the cutoffs set at 0 from below and 100 from above.

Figures $10 \mathrm{a}$ and $10 \mathrm{~b}$ show that the effect sizes are substantially magnified for the NSL's negative impacts on pro-democracy camp's ACGT across all model specifications and trust in Hong Kong's local executive institutions - the Chief Executive and the Police - , but the patterns remain the same. In other words, our previous findings about the bifurcated effects the NSL had on prodemocracy and pro-establishment camps' institutional trusts are robust to the data censoring in our design. We also estimated several augmented specifications with additional controls for Hong Kong's local institutions, and the results still hold. See Appendix E.1 for details.

\footnotetext{
${ }^{25}$ See Figure E.1 in Appendix E.1 for the bounds estimates for the individual Central Government institutions. The results also confirm the robustness of our baseline estimations.
} 
(a) Average Central Government Trust

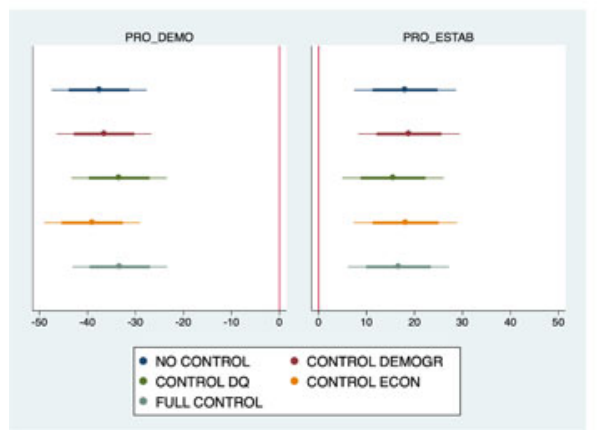

(b) Hong Kong's Local Institutions

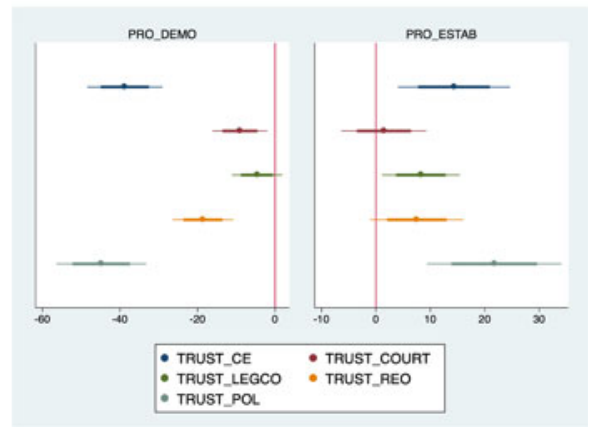

Figure 10. Coefficients plots for the NSL's effects on institutional trusts by political stances (Tobit estimates).

\subsubsection{Endogeneity}

Furthermore, since one's political stance choice could be endogenous to his or her institutional trust, we took a machine-learning approach by using the KNN ( $K$-nearest neighbors) algorithm to find a totally exogenous proxy for one's political stance. For each respondent's choice of stance, the algorithm determined which other ones were 'nearest' to it in the parameter space composed of the variables of economic and political attitudes in the surveys that were essential to identifying its 'neighbors,' i.e., those who held very similar attitudes with the respondent in question along these dimensions. The algorithm then assigned a predicted political stance based on the most frequent choice among the identified nearest neighbors. This approach exploits the fact that individual survey responses in our surveys were independent of each other, and therefore one's newly assigned political stance based on the KNN algorithm would be entirely exogenous to his or her choice of institutional trust. ${ }^{26}$

As Figure 11a shows, while the magnitude of the NSL effects on the ACGT across all specifications among pro-democracy camp is slightly larger, their signs and statistical significance remain the same as the baseline estimations above. For the same set of institutions, the results in Figure 11b also show that our baseline estimates for the effects of protest expectations are robust. Regarding Hong Kong's local institutions, we can find from the estimates documented in Figures 12a and 12b that, despite some differences in magnitude, for both the effects of the NSL and protest expectations, they are very consistent with the baseline results. Combined, all the KNN-based estimations above confirm the robustness of our previous empirical findings to potential endogeneity. ${ }^{27}$

\subsubsection{Different cutoffs for CA (protest expectations)}

In our third set of robustness tests, we tried to see if our main results for the first-differenced institutional trust in the Central Government (ACGT) remained stable under different cutoff choices for dichotomizing CA. ${ }^{28}$ We adopted two approaches. First of all, since our initial cutoff was 4 (>3.79), we compared its $t$-statistic with the counterparts under the cutoffs of 3 and 5 , respectively, for the baseline model (1) in Table 4 - i.e., the coefficient of the interaction term between protest expectations and the stance dummy of pro-democracy camp. As Figure 13a - the red bar represents the $t$-statistics based on our initial choice - shows, changing the cutoff to either direction doesn't affect the statistical

\footnotetext{
${ }^{26}$ See Appendix E.2.1 for the list of variables we used for estimating attitudinal distance to finding one's nearest neighbors, stance-wise percentages of matches between original and KNN-based classifications, and the regression results for all the KNN-based estimations whose coefficient plots are presented below.

${ }^{27}$ Alternatively, we also conducted another robustness test by using one's pre-NSL political stance instead for estimating the effect of protest expectations on institutional trust. See Appendix E.2.2 for the results. Since one's own pre-NSL political stance is entirely exogenous to his or her post-NSL institutional trust, the fact that the regression results remain consistent and stable confirms again that our baseline estimations are robustness to endogeneity.

${ }^{28}$ To save space, See Figures E.2 and E.3 in Appendix E.3 for the results of other institutions.
} 
(a) The NSL Effect

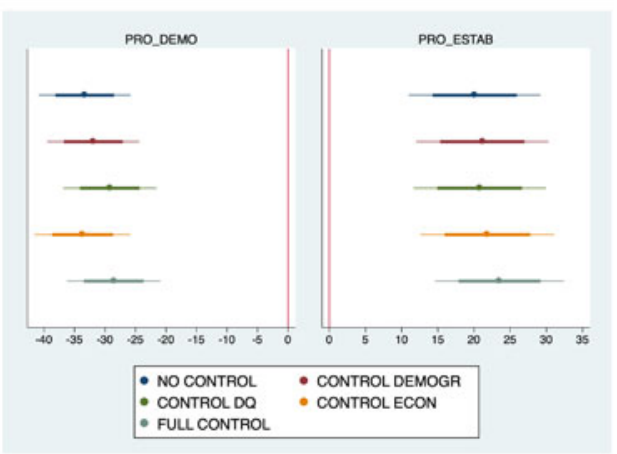

Figure 11. KNN-based estimations: ACGT.

(a) The NSL Effect

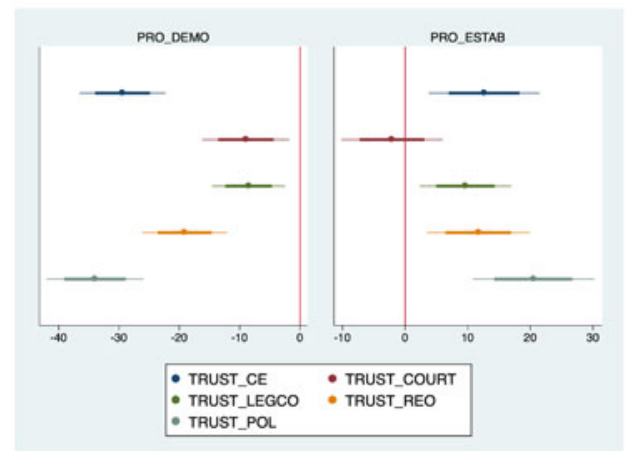

(b) Protest Expectations

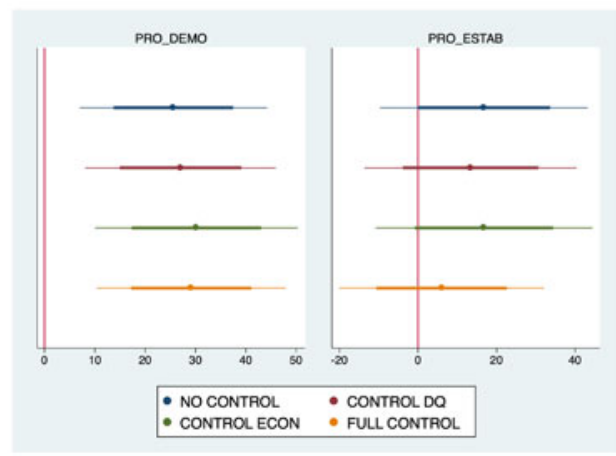

Figure 12. KNN-based estimations: Hong Kong's local institutions.

(a) Neighboring Cutoffs

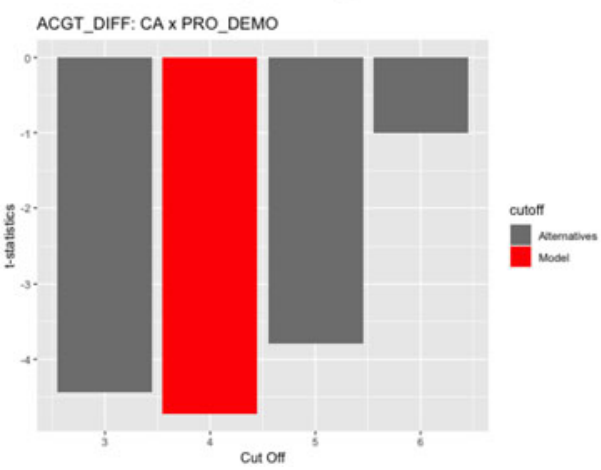

(b) Protest Expectations

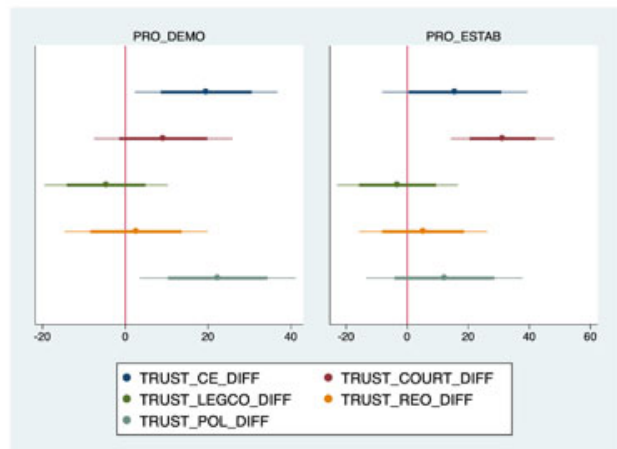

(b) Simulations

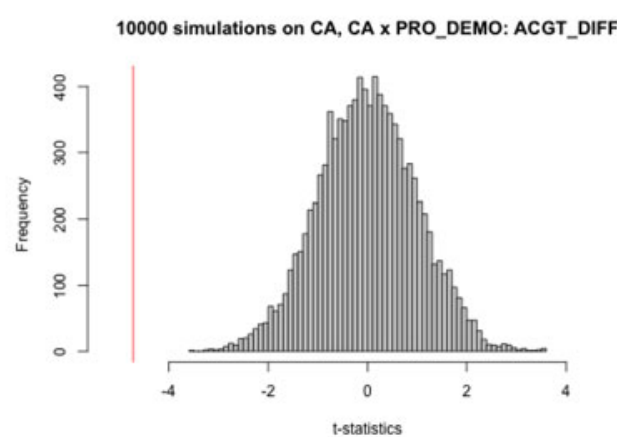

Figure 13. Different cutoffs of CA.

significance for the other coefficients. This implies that our baseline result is robust to different CA cutoffs.

Alternatively, we also adopted Deaton and Cartwright's (2018) and Cantoni et al.'s (2019) approach to randomly assign (fictional) CA groupings to our samples and estimated their effects for 10,000 
times. Next, the $t$-statistics from the estimated effects for all the fictional trials were derived and compared to that under the initial CA cutoff for the same coefficient. This method helps us confirm that the effect we found is statistically very different from those based on random cutoffs and therefore is robust. Figure $13 \mathrm{~b}$ - the vertical red line indicates the $t$-statistics from the initial CA assignment clearly shows that our result is far from random.

\section{Concluding remarks}

In the wake of the recent military coup in Myanmar, we have witnessed again how dictators dealt with their opponents at home. While we often see violent repressions in dictators' toolkit, they are certainly not the only means through which authoritarian stability is restored or a new dictatorship is crafted. In fact, Hong Kong is exactly such a case where the authoritarian government is trying to legitimize its not-so-violent repressive acts through the existing legal and political framework. This is why, even when most people would unambiguously announce the 'One Country, Two Systems' framework dead, Beijing has insisted on using the name and refused to replace the current framework with a completely new one.

The success of such a strategy, however, critically hinges on how trustworthy the post-repression institutions are among Hong Kongers. Our study, therefore, provides a comprehensive and timely assessment of the current status of Hong Kong's institutional landscape and an answer to the question this paper began with: 'How does repression on opposition protests affect citizens' institutional trust under dictatorships?' Our findings are twofold. First of all, the NSL as a soft repression drove a wedge in the Hong Kong society by making the pro-establishment camp (self-perceived regime insiders) - and no stancers to a lesser degree - more satisfied with the post-NSL institutions on the one hand, while alienating the prodemocracy camp (self-perceived regime outcasts) who lost tremendous trust in them on the other. This bifurcation confirms our regime inclusiveness hypothesis. For the literature on institutional trust, the finding suggests that the effect of repression on institutional trust under dictatorships is substantially correlated with one's sense of regime inclusiveness. Especially, during the time of turmoil, long-term ideological inclinations have become less relevant than short-term political fluctuations as a determinant, our timely study shows that a dictator's ability (or inability) to coopt citizens can be critical in determining institutional trust in an institutional environment without procedural legitimacy.

Second, our study also reveals that one's trust in institutions is significantly associated with the regimes' ability to curb protesters' contentious mobilization and restore social stability. More specifically, as our informational perspective predicts, we find that the Hong Kongers who had higher confidence in the NSL to rein in protests would also have a greater level of trust than those who didn't. Moreover, while this correlation applies to all the political stripes, the effect was substantially smaller among prodemocracy Hong Kongers except for their trust in monitoring institutions (i.e., the Court, the LegCo, and the Registration and Electoral Office). This effect heterogeneity implies a critical political dynamics in post-NSL Hong Kong. On balance, as long as the NSL was viewed as an effective tool in repressing protests, it helped command pro-establishmentarians' higher institutional trusts across the board. As for democrats, while the NSL did wreck their trusts in all the executive institutions involved in enforcing Beijing's political agenda, it didn't make them equally disillusioned with the monitoring institutions.

This finding illustrates not only Escribá-Folch's (2013) general argument about the soft repression in Hong Kong's political context, but also, more profoundly, the social foundation for a potential road map according to which a new dictatorship can be crafted. Namely, as Beijing is transforming Hong Kong's political system from within in hopes of bringing about a new equilibrium to its politics without strong resistance, exploiting the pro-democracy camp's remaining trust in the monitoring institutions seems to be optimal. Some examples we have witnessed since the passage of the NSL include convicting dissidents and protesters through the Court, ${ }^{29}$ forming new pro-Beijing political

\footnotetext{
${ }^{29}$ Emily Feng. '9 Hong Kong Pro-Democracy Activists Sentenced For 2019 Protests.' NPR 16 April 2012. Available at: https://www.npr.org/2021/04/16/987959427/9-hong-kong-pro-democracy-activists-sentenced-for-2019-protests (accessed: 22 April 2021).
} 
parties, ${ }^{30}$ and manipulating the electoral rules the Registration and Electoral Office will be in charge of administering for the Chief Executive and the LegCo elections. ${ }^{31}$ While these political maneuverings are certainly objectionable to pro-democracy Hong Kongers, the wide support these institutions enjoy can still allow Beijing's institutional engineering to be gradually unfolded and erode Hong Kong's protest-based model of accountability.

Supplementary material. The supplementary material for this article can be found at https://doi.org/10.1017/ S1468109921000293 and https://dataverse.harvard.edu/dataset.xhtml?persistentId=doi:10.7910/DVN/ZCLECH.

Conflict of interest. The authors declare none.

\section{References}

Boix C and Svolik MW (2013) The foundations of limited authoritarian government: institutions, commitment, and powersharing in dictatorships. Journal of Politics 75, 300-316.

Cantoni D, Yang DY, Yuchtman N and Zhang YJ (2019) Protests as strategic games: experimental evidence from Hong Kong's anti-authoritarian movement. Quarterly Journal of Economics 134, 1021-1077.

Chan J and Chan E (2006) Charting the state of social cohesion in Hong Kong. China Quarterly 187, 635-658.

Cheng EW (2016) Street politics in a hybrid regime: The diffusion of political activism in post-colonial Hong Kong. China Quarterly 226, 383-406.

Curtice TB and Behlendorf B (2021) Street-level repression: protest, policing, and dissent in Uganda. Journal of Conflict Resolution 65, 166-194.

Deaton A and Cartwright N (2018) Understanding and misunderstanding randomized controlled trials. Social Science and Medicine 210, 2-21.

Desposato SW, Wang G and Wu JY (2021) The long-term impact of mobilization and repression on political trust. Comparative Political Studies forthcoming.

Dinas E and Northmore-Ball K (2020) The ideological shadow of authoritarianism. Comparative Political Studies 53, 19571991.

Easton D (1975) A re-assessment of the concept of political support. British Journal of Political Science 5, 435-457.

El-Mallakh N (2020) How do protests affect electoral choices? Evidence from Egypt. Journal of Economic Behavior and Organization 179, 299-322.

Escribá-Folch A (2013) Repression, political threats, and survival under autocracy. International Political Science Review 34, 543-560.

Fong BCH (2013) State-society conflicts under Hong Kong's hybrid regime: governing coalition building and civil society challenges. Asian Survey 53, 854-882.

Frye T and Borisova E (2019) Elections, protest, and trust in government: a natural experiment from Russia. Journal of Politics 81, 820-832.

Gandhi J (2008) Political Institutions Under Dictatorship. New York, N.Y.: Cambridge University Press.

Kim W and Gandhi J (2010) Coopting workers under dictatorship. Journal of Politics 72, 646-658.

Kuran T (1997) Private Truths, Public Lies: The Social Consequences of Preference Falsification. Cambridge, MA: Harvard University Press.

Lawrence AK (2016) Repression and activism among the Arab Spring's first movers: evidence from Morocco's February 20th movement. British Journal of Political Science 47, 699-718.

Lee DS (2009) Training, wages, and sample selection: estimating sharp bounds on treatment effects. Review of Economic Studies 76, 1071-1102.

Lhrmann A and Lindberg SI (2019) A third wave of autocratization is here: what is new about it? Democratization 26, 1095-1113.

Ma N (2007) Political Development in Hong Kong: State, Political Society, and Civil Society. Hong Kong: Hong Kong University Press.

Madestam A, Shoag D, Veuger S and Yanagizawa-Drott D (2013) Do political protests matter? Evidence from the Tea Party Movement. Quarterly Journal of Economics 128, 1633-1685.

Mazumder S (2018) The persistent effect of U.S. Civil rights protests on political attitudes. American Journal of Political Science 62, 922-935.

\footnotetext{
${ }^{30}$ Jeff Pao. 'New pro-Beijing party to seek HK hearts and minds.' Asia Times 10 March 2021. Available at: https://asiatimes. com/2021/03/new-pro-beijing-party-to-seek-hk-hearts-and-minds/ (accessed: 30 March 2021).

${ }^{31}$ John Sudworth. 'China's parliament remakes Hong Kong in its own image.' BBC 11 March 2021. Available at: https:// www.bbc.com/news/world-asia-china-56364912 (accessed: 30 March 2021).
} 
Neundorf A and Pop-Eleches G (2020) Dictators and their subjects: authoritarian attitudinal effects and legacies. Comparative Political Studies 53, 1839-1860.

Neundorf A, Gerschewski J and Olar R-G (2020) How do inclusionary and exclusionary autocracies affect ordinary people? Comparative Political Studies 53, 1890-1925.

Rozenas A and Zhukov YM (2019) Mass repression and political loyalty: evidence from Stalin's 'Terror by Hunger'. American Political Science Review 113, 569-583.

Sangnier M and Zylberberg Y (2017) Protests and trust in the state: evidence from African countries. Journal of Public Economics 152, 55-67.

Tertytchnaya K and Lankina T (2020) Electoral protests and political attitudes under electoral authoritarianism. Journal of Politics 82, 285-299.

Wang Y (2021) The political legacy of violence during China's cultural revolution. British Journal of Political Science 51, 463-487.

Cite this article: Tung HH, Lin M-J, Lin Y-F (2021). Anti-ELAB Movement, National Security Law, and heterogeneous institutional trust in Hong Kong. Japanese Journal of Political Science 22, 287-311. https://doi.org/10.1017/S1468109921000293 